\title{
The Importance of Epigenetics in Diagnostics and Treatment of Major Depressive Disorder
}

\author{
Piotr Czarny ${ }^{1,+}{ }^{\mathbb{D}}$, Katarzyna Białek $^{2,+}$, Sylwia Ziółkowska ${ }^{1,+}$, Justyna Strycharz ${ }^{1} \mathbb{D}$, Gabriela Barszczewska ${ }^{2}$ \\ and Tomasz Sliwinski ${ }^{2, * \mathbb{C}}$ \\ 1 Department of Medical Biochemistry, Medical University of Lodz, 92-216 Lodz, Poland; \\ piotr.czarny@umed.lodz.pl (P.C.); sylwia.ziolkowska@stud.umed.lodz.pl (S.Z.); \\ justyna.strycharz@umed.lodz.pl (J.S.) \\ 2 Laboratory of Medical Genetics, Faculty of Biology and Environmental Protection, University of Lodz, \\ 90-236 Lodz, Poland; biaalek.k@gmail.com (K.B.); gabriela.barszczewska@edu.uni.lodz.pl (G.B.) \\ * Correspondence: tomasz.sliwinski@biol.uni.lodz.pl \\ + Equal contribution.
}

check for updates

Citation: Czarny, P.; Białek, K.; Ziółkowska, S.; Strycharz, J.; Barszczewska, G.; Sliwinski, T. The Importance of Epigenetics in Diagnostics and Treatment of Major Depressive Disorder. J. Pers. Med. 2021, 11, 167. https://doi.org/ 10.3390/jpm11030167

Academic Editors: Piotr Galecki and Kuan-Pin Su

Received: 31 December 2020

Accepted: 17 February 2021

Published: 1 March 2021

Publisher's Note: MDPI stays neutral with regard to jurisdictional claims in published maps and institutional affiliations.

Copyright: (c) 2021 by the authors. Licensee MDPI, Basel, Switzerland. This article is an open access article distributed under the terms and conditions of the Creative Commons Attribution (CC BY) license (https:/ / creativecommons.org/licenses/by/ $4.0 /)$.

\begin{abstract}
Recent studies imply that there is a tight association between epigenetics and a molecular mechanism of major depressive disorder (MDD). Epigenetic modifications, i.e., DNA methylation, post-translational histone modification and interference of microRNA (miRNA) or long non-coding RNA (lncRNA), are able to influence the severity of the disease and the outcome of the therapy. This article summarizes the most recent literature data on this topic, i.e., usage of histone deacetylases as therapeutic agents with an antidepressant effect and miRNAs or lncRNAs as markers of depression. Due to the noteworthy potential of the role of epigenetics in MDD diagnostics and therapy, we have gathered the most relevant data in this area.
\end{abstract}

Keywords: depression; epigenetics; personalized medicine; histones; histone modifications; DNA methylation; microRNA; long non-coding RNA

\section{Introduction}

Major depressive disorder (MDD) is a chronic, highly recurrent and clinically heterogeneous disease, also known simply as depression. It is characterized by high worldwide prevalence and increased risk for suicidal death [1,2]. MDD is no longer believed to be triggered by just one factor (e.g., biological, psychosocial, behavioral), but rather to occur due to interactions among several of them during one's lifetime [2]. Considering genetics, the recent genome-wide association meta-analysis involving 135,458 MDD patients and 344,901 control subjects elucidated 44 independent risk variants, including 30 novel ones [3]. Nevertheless, the meta-analysis of five studies on twins estimated the heritability of the disease to account for $37 \%$ [4]. Therefore, it becomes clear that susceptibility to depression is not entirely explained by changes found in a DNA sequence. As the response to environmental stressors is diverse, stress exposure may evoke depression only in some individuals. Thus, it is not surprising that a current view on the etiology of depression is rather to perceive environmental and genetic factors as interacting with and modulating one another ( $\mathrm{G} \times \mathrm{E}$-gene-environment) [5]. Recently, a third plausible contributory factor has emerged called epigenetics. The latter denotes gene expression regulation via modifications not encoded/found in DNA nucleotide sequence, yet heritable and sensitive to environmental influence. The whole repertoire of epigenetic mechanisms is believed to enable a crosstalk among environment and genetics, thus respectively affecting the phenotype. A large body of evidence indicates not only that epigenetic factors may contribute to depression pathogenesis, but also have an impact on responses of individuals to pharmacotherapy. This appears to be an especially intriguing issue due to the fact that drug resistance is attributable to one-third of treated subjects $[6,7]$. Three well-known 
epigenetic mechanisms that sophisticatedly control the expression of genetic information are: (i) fifth carbon atom methylation of cytosine within its heterocyclic aromatic ring generating 5-methylcytosine $(5 \mathrm{mC})$ [8] and its oxidation into 5-hydroxymethylcytosine $(5 \mathrm{hmC})$ [9]; (ii) remodeling of chromatin via numerous covalent modifications, e.g., methylation, acetylation, phosphorylation, SUMOylation mainly in N-terminal tails of core histones [5]; (iii) actions mediated by non-coding RNAs, such as microRNAs (miRNAs) and long non-coding RNAs (lncRNAS) [10,11]. The above mechanisms stay in crosstalk among one another so as to coordinately change the phenotype. For instance, expression of miRNAs and lncRNAs is regulated via DNA methylation and remodeled chromatin, while DNA methylation marks (5-methylcytosines) are capable of recruiting modifying enzymes to histones [12]. Furthermore, more and more studies explore the impact of lncRNAs on miRNAs (e.g., acting as miRNA sponges) eliciting changes of target mRNAs in numerous diseases, including Alzheimer's [13].

The exact mechanisms of molecular pathogenesis of depression are still not known, including the involvement of epigenetic ones. Thus, this review provides a summary of the state of the art of the association among epigenetics and pathogenesis and MDD therapy, while outlining promising directions for future research. We used Google Scholar and PubMed in order to review the most relevant papers focusing on epigenetic modifications in the context of diagnostics and treatment of major depressive disorder published until December 2020. We considered studies performed on animals as well as human subjects (in vivo, in vitro) along with clinical trials. Keywords applied were as follows: major depressive disorder, depression, depression biomarkers, depression diagnostics, microRNA, miRNA, lncRNA, DNA methylation, promoter methylation, histone modifications, histone acetylation, histone methylation, neuroplasticity, synaptic plasticity, neuroinflammation, depression therapy, antidepressants, nervous system, brain, blood, serum, plasma, cerebrospinal fluid.

\section{DNA Methylation}

\subsection{DNA Methylation in Depression}

One of the best-known heritable patterns of modifications that affect gene expression, which cannot be attributed to changes in the primary DNA sequence, is DNA methylation. Therefore, it is one of the most extensively studied epigenetic modifications in humans. This mechanism is mediated by a family of DNA methyltransferases (DNMTS), with DNMT3A/DNMT3B being responsible for de novo methylation and DNMT1 recognizing hemi-methylated DNA. The process occurs with the covalent addition of a methyl group almost exclusively at the cytosine base in $5^{\prime}$ position into the major groove of DNA leading to creation of 5-methylocytosine $(5 \mathrm{mC})$. In mammals, DNA methylation predominantly occurs at palindromic sequence of cytosine-guanine dyads (CpG sites) within the promoter regions, yet, it is also found inside a coding sequence of the gene. The regulatory role of DNA methylation has been implicated in gene expression control, especially in transcription repression, due to reducing access of transcription factors to regulatory elements [8]. As approximately $3 \%$ of cytosines are methylated [14] in the human genome, it plays a pivotal role in many biological processes such as gene imprinting, chromosomal inactivation, cell differentiation, repetitive elements silencing [8]. An important discovery proved that $5 \mathrm{mC}$ could be modified via oxidation into 5-hydroxymethylcytosine $(5 \mathrm{hmC})$; it was reported in mammals in 2009 for the first time [9]. This process is called DNA demethylation and is catalyzed by ten-eleven translocation (TET) enzymes. Although it is present in many tissue types, $5 \mathrm{hmC}$ is found to be especially abundant in neuronal cells of the brain. It is hypothesized that DNA methylation may play an important role in mediating stress effects. Moreover, methylation could establish gene silencing by its cooperation with histone modifications. Specifically, it is proposed that the mentioned interrelation may be mediated by proteins such as Zinc finger and BTB domain-containing protein 33 (ZBTB 33), methyl-CpG-binding protein 2 (MeCP2) and methyl-CpG-binding domain 
protein 1 (MBD1), which present methyl DNA binding activity and ability for recruitment of protein complex containing histone deacetylases (HDACs) and methyltransferases [15].

DNA methylation is among several epigenetic modifications especially interesting in the context of neuropsychiatric diseases. Environmental factors, which often influence disease trajectories, are able to modify methylation patterns $[16,17]$. Recent evidence indicates that alterations in DNA methylation, i.e., both hyper- and hypomethylation at the same loci as well as methylation variance, are frequently present in depressed individuals [18]. Methylation patterns are also characterized by great stability, therefore they could serve as possible biomarkers of the disease and even might be helpful in predicting treatment improvements [19]. Most of the knowledge accumulated to date on epigenetic mechanisms in depression comes from animal studies; however, these results have recently been confirmed in human research (Table 1). A particularly adequate way for studying epigenetic changes is to observe them in monozygotic twins, since they have nearly the same DNA sequence, but their methylation profiles could be different due to environmental or stochastic factors [20]. Interestingly, identification of differentially methylated probes (DMPs) and variably methylated probes (VMPs) evaluated discrepancies in DNA methylation between monozygotic twins and revealed a link between their psychopathological characteristic and those differences [21].

Table 1. Summary of the human studies assessing DNA methylation in depressive disorders.

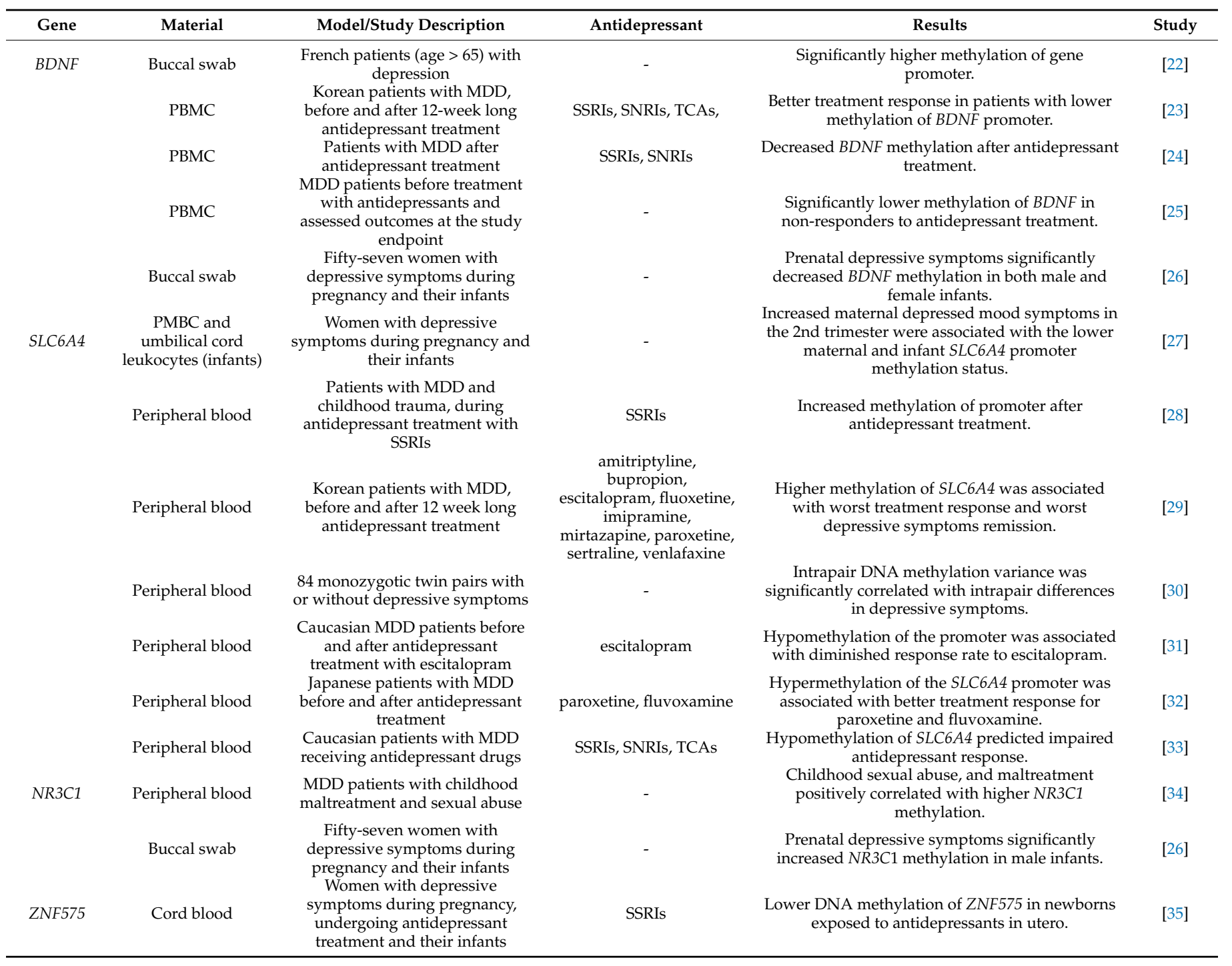


Table 1. Cont.

\begin{tabular}{|c|c|c|c|c|c|}
\hline Gene & Material & Model/Study Description & Antidepressant & Results & Study \\
\hline PPFIA4 & Peripheral blood & $\begin{array}{l}\text { Japanese patients with MDD } \\
\text { receiving antidepressant drugs }\end{array}$ & paroxetine & $\begin{array}{l}\text { Difference in promoter methylation was } \\
\text { significantly correlated with treatment response } \\
\text { to paroxetine. }\end{array}$ & [36] \\
\hline HS3ST1 & Peripheral blood & $\begin{array}{l}\text { Japanese patients with MDD } \\
\text { receiving antidepressant drugs }\end{array}$ & paroxetine & $\begin{array}{c}\text { Difference in promoter methylation was } \\
\text { significantly correlated with treatment response } \\
\text { to paroxetine. }\end{array}$ & [36] \\
\hline$I L-11$ & Peripheral blood & $\begin{array}{l}\text { Caucasian European patients } \\
\text { with MDD receiving } \\
\text { escitalopram or nortriptyline }\end{array}$ & $\begin{array}{l}\text { escitalopram, } \\
\text { nortriptyline }\end{array}$ & $\begin{array}{l}\text { Lower methylation was associated with better } \\
\text { treatment response; higher methylation was } \\
\text { associated with better response to escitalopram, } \\
\text { but with worse response to nortriptyline. }\end{array}$ & [37] \\
\hline TPH2 & Peripheral blood & Han Chinese patients with MDD & $\begin{array}{l}\text { SSRIs, SNRIs, SARIs, } \\
\text { antipsychotic drugs }\end{array}$ & $\begin{array}{l}\text { Hypomethylation was associated with treatment } \\
\text { response rate. }\end{array}$ & {$[38]$} \\
\hline
\end{tabular}

PBMC—Peripheral blood mononuclear cell, MDD—major depressive disorder, SSRI—serotonin selective reuptake inhibitor, SNRI— serotonin norepinephrine reuptake inhibitor, TCAs—-tricyclic antidepressants.

\subsubsection{Brain-Derived Neurotrophic Factor (BDNF) Gene Methylation in Depression}

The first genome-wide DNA methylation scan in depressed patients identified significant DNA methylation differences located in genes connected with neuronal growth and development [39]. It has been demonstrated that increased DNA methylation of the brain-derived neurotrophic factor $(B D N F)$ gene, encoding the protein responsible for neuronal growth, differentiation and plasticity, is connected with depression in the human population [40]. It is established that BDNF could be involved in behavioral phenomena connected with depressive disorders as well as antidepressant treatment effectiveness. Higher methylation status of CpG in BDNF promoter region correlated with significantly lower synthesis of this factor in neurons [41]. Moreover, it has been confirmed that patients with depressive symptoms and those with suicidal ideation displayed increased methylation level of $B D N F$ promoter [22,40,42]. Interestingly, during antidepressant treatment, a trend of decreasing $B D N F$ methylation was observed [24].

Epigenetic modifications occurring in early life and even in utero may have long-term effects in later age. Together with environmental factors they could play an important role in development of neuropsychiatric diseases, including depression. For instance, maternal depressive symptoms during the prenatal period are frequently associated with hypomethylation of $B D N F$ promoter in infants [26]. This statement is also confirmed by animal studies (Table 2), where methylation alterations were found in rats subjected to the animal model of childhood maltreatment, suggesting its association with stressful early-life experience $[18,43]$. Rodent studies indicated that caregiver ill-treatment caused an increased methylation of $B D N F$ in the prefrontal cortex [43].

Table 2. Summary of the animal studies assessing DNA methylation in depressive disorders.

\begin{tabular}{|c|c|c|c|c|c|}
\hline Gene & Material & Study Description & Antidepressant & Results & Study \\
\hline \multirow[t]{2}{*}{$B D N F$} & $\begin{array}{l}\text { Prefrontal cortex } \\
\text { and hippocampus }\end{array}$ & $\begin{array}{l}\text { Rat model of infant maltreatment } \\
\text { by a caregiver }\end{array}$ & - & Increased methylation of $B D N F$ in the prefrontal cortex & {$[25]$} \\
\hline & Hippocampus & $\begin{array}{l}\text { Mouse model of post-stroke } \\
\text { depression }\end{array}$ & Fluoxetine & $\begin{array}{l}\text { Increased methylation of BDNF promoter in hippocampus as } \\
\text { well as reduction in depressive behavior }\end{array}$ & [44] \\
\hline NR3C1 & hippocampus & $\begin{array}{l}\text { Rat model: pups with increased } \\
\text { frequency of licking, grooming } \\
\text { and arched-back nursing by } \\
\text { mother versus neglected rats }\end{array}$ & - & $\begin{array}{l}\text { Offspring neglected by a mother showed changes in GR } \\
\text { methylation levels }\end{array}$ & [23] \\
\hline THP1 & PBMC & $\begin{array}{l}\text { Rats subjected to chronic mild } \\
\text { stress procedure and } \\
\text { administrated with venlafaxine }\end{array}$ & venlafaxine & Increased methylation status after antidepressant therapy & [45] \\
\hline GPX4 & PBMC & $\begin{array}{l}\text { Rats subjected to chronic mild } \\
\text { stress procedure and } \\
\text { administrated with agomelatine }\end{array}$ & agomelatine & Decreased methylation status after antidepressant therapy & [46] \\
\hline NOS1 & Brain tissues & $\begin{array}{l}\text { Rats subjected to chronic mild } \\
\text { stress procedure and } \\
\text { administrated with agomelatine }\end{array}$ & agomelatine & $\begin{array}{l}\text { Decreased methylation status of gene promoter in amygdala } \\
\text { and basal ganglia after antidepressant therapy }\end{array}$ & [46] \\
\hline GPX1 & Brain tissues & $\begin{array}{l}\text { Rats subjected to chronic mild } \\
\text { stress procedure and } \\
\text { administrated with agomelatine }\end{array}$ & agomelatine & $\begin{array}{l}\text { Decreased methylation status of gene promoter in } \\
\text { hippocampus and hypothalamus after antidepressant therapy }\end{array}$ & [46] \\
\hline$C A T$ & Brain tissues & $\begin{array}{l}\text { Rats subjected to chronic mild } \\
\text { stress procedure and } \\
\text { administrated with agomelatine }\end{array}$ & agomelatine & $\begin{array}{l}\text { Decreased methylation status of gene promoter in cerebral } \\
\text { cortex after antidepressant therapy }\end{array}$ & [46] \\
\hline
\end{tabular}

PBMC-Peripheral blood mononuclear cell, GR—Glucocorticoid receptor. 


\subsubsection{SLC6A4 Gene Methylation in Depression}

A growing body of evidence suggests that the same trend is observed in the case of encoding for serotonin transporter SLC6A4 gene, which has been especially well-studied in the context of serotonergic signaling in depression. Serotonin transporter plays a critical role in MDD, since it is responsible for serotonin turnover and level in synaptic cleft. Therefore, any disturbances of SLC6A4 may contribute to depression pathogenesis, by causing dysregulation of the serotonergic system. Consistent with $B D N F$, maternal mood disturbances during a pregnancy period have been connected with decreased methylation status of SLC6A4 in umbilical cord leukocytes of newborns [27]. However, a majority of recent evidence demonstrates an increase in DNA methylation of SLC6A4 in patients with depressive disorders $[8,28,30,42]$. Moreover, promoter hypermethylation of the gene in peripheral blood was associated with a worse clinical outcome [29]. Studies using functional magnetic resonance imaging (fMRI) showed that higher methylation of SLC6A4 promoter was connected with hippocampal volume and higher frontal-limbic response to negative stimulation in MDD subjects [47,48].

\subsubsection{NR3C1 Gene Methylation in Depression}

Among the potential candidate genes is the NR3C1 gene, which encodes a glucocorticoid receptor (GR), an essential factor for sufficient hypothalamic-pituitary-adrenal (HPA) axis functioning. Precisely, cortisol, upon binding to GR, induces a cascade of stress-related responses to stress stimuli. Therefore, GR plays a pivotal role in termination of stress response by mediating negative feedback regulation of the HPA axis. This mechanism could be affected by variety of factors, and it is proposed that NR3C1 methylation may be considered a feasible explanation for understanding HPA axis dysregulation, frequently occurring in depression [8]. Despite extensive research, results are inconsistent. On the one hand, there is some evidence for hypermethylation of the NR3C1 gene in depressed females and their offspring [17]. On the other hand, recent research reported no association between its methylation and depression [8]. Moreover, animal studies indicated that offspring neglected by a mother showed changes in GR methylation levels in tissues from the hippocampus [49]. Confusingly, depressed patients who had experienced early sexual abuse and maltreatment, presented increased methylation of NR3C1 promoter. Moreover, this methylation status was positively correlated with the severity of mistreatment [34].

\subsection{DNA Methylation and Antidepressant Treatment}

\subsubsection{Human Research}

Epigenetic mechanisms are more often studied in the context of depression treatment. What is more, recent work focuses on biological predictors for drug response, identifying a modern approach to therapeutic strategies. This field is called pharmacogenetics (PGx) and provides opportunity for improved prognostication of response and tolerability of different medications. Growing research examines ways and mechanisms in which epigenetic marks predict treatment outcomes as a part of pharmacoepigenetics. There are some pieces of evidence suggesting that antidepressants deliver their effect at least partially through epigenetic modifications. An increasing amount of data indicate that epigenetic changes observed in patients with depressive disorders could act as predictors of antidepressant treatment response. Antidepressants may also have the ability to alter or even reverse epigenetic modifications, and therefore, it has been proposed that treatment response might be indicated by methylation status of some genes. In patients with post-stroke depression (PTSD), NR3C1 methylation was associated with treatment outcome [50]. What is even more interesting, research conducted on pregnant women undergoing antidepressant treatment revealed that newborns exposed to antidepressants during pregnancy had lower DNA methylation of Zinc Finger Protein 575 (ZNF575) gene sequence [35]. The clinical data suggest that SLC6A4 promoter methylation status might be a possible marker for treatment response prognosis. Specifically, promoter hypomethylation of the gene has been linked with diminished response rate to escitalopram. It could 
have been caused by increased expression/activity of serotonin transporters, and therefore, insufficient availability of this neurotransmitter in the synaptic cleft [31]. This is in line with another study, which found that decreased methylation of SLC6A4 promoter predicted diminished dimensional and categorical response to serotonergic antidepressant drugs [33]. Interestingly, hypermethylation of the SLC6A4 promoter has been associated with improved treatment response for antidepressants, such as paroxetine and fluvoxamine [32] as well as escitalopram [31]. A large study investigated the role of $B D N F$ methylation in MDD patients and its association with depression therapy. Lower methylation of $B D N F$ promoter has been linked with antidepressant response rate, predicting non-responsiveness to multiple classes of antidepressants, including selective serotonin reuptake inhibitors (SSRIs), selective norepinephrine reuptake inhibitors (SNRIs), tricyclic antidepressants (TCAs), and monoamine oxidase inhibitors (MAOIs) [25]. In addition, BDNF methylation could be regulated by DNMT1 according to antidepressant response to paroxetine [51]. Similarly, methylation of PTPRF Interacting Protein Alpha 4 (PPFIA4) and Heparan SulfateGlucosamine 3-Sulfotransferase 1 (HS3ST1) genes was associated with therapeutic response to paroxetine [36]. Moreover, another potential predictor of treatment outcome might be an epigenetic status of interleukin 11 (IL-11) promoter, as it has been found that methylation of several CpG sites could be used to estimate whether an individual is likely to respond to antidepressants [37]. It is suggested that serotonin receptor 1A and 1B (HTR1A/1B) genes methylation could be involved in the pathogenesis of MDD and treatment response. It is indicated that hypomethylation of those genes and their interplay with stress stimuli might cause worsening of antidepressant treatment outcome. As mentioned, there are various mechanisms by which antidepressant drugs and their compounds could alter epigenetic marks. Some data suggest that amitriptyline and imipramine belonging to TCAs as well as SSRI (paroxetine), show an ability to reduce DNMT activity, and thus decrease DNA methylation [52]. Paroxetine has also been found to affect DNMT activity by changing its phosphorylation [51]. There are also studies reporting that methylation of the tryptophan hydroxylase 2 (TPH2) gene could predict response to antidepressants as well as interaction between hypomethylation and early-life stress may be associated with worse treatment outcome [38].

\subsubsection{Animal Models of Depression}

Studies on animal models of depression are in line with results from human research. For instance, the methylation status of the TPH1 in peripheral blood mononuclear cells (PBMCs) was found to be significantly increased after antidepressant therapy with venlafaxine [45]. There are also results indicating that agomelatine administration reduced methylation of Glutathione Peroxidase 4 (GPX4) promoter in PBMC as well as Nitric Oxide Synthase 1 (NOS1), Glutathione Peroxidase 1 (GPX1) and Catalase (CAT) promoters in brain tissues of rats subjected to chronic mild stress [46]. Post-treatment observations showed that fluoxetine increased methylation of $B D N F$ promoter in mice hippocampal tissues, which was also associated with a reduction in depressive behaviors [44]. Moreover, chronic imipramine distribution reversed methylation of a CpG within the HTR1A promoter in the prefrontal cortex and midbrain of mice [53], as well as corticotropin-releasing factor $(C R F)$ gene in the mice hypothalamus [54], which were induced by stress stimuli. Furthermore, imipramine administration has been connected to decreasing stress-induced global DNA methylation and DNMT activity in the prefrontal cortex of rats [55]. It was also demonstrated that DNMT inhibitors enhanced the effect of conventional antidepressants and improved depressive-like behaviors in mice [56,57].

To conclude, the methylation rate of numerous genes may display predictive function for evaluating the effectiveness of antidepressant treatment. However, while exploring DNA methylation marks as biomarkers, it is important to design experiments that assess and account for a variety of potential confounders, including socioeconomic and demographic factors. 


\section{Histone Modifications}

Histone modifications, more precisely, post-translational modifications (PTMs), and their functions are tightly related to gene expression control. There is a hypothesis assuming that the sum of these modifications, the so-called histone code, influences the expression level of targeted genes [58]. In the last decade, a lot of research has been focused on the association between the PTMs and neuropsychiatric diseases, and a growing number of researchers have noticed how important and evident this relationship is. In the case of depression studies, most attention has been paid to acetylation and methylation of histones.

Due to the inverse action of acetylation and deacetylation, they are able to control the chromatin condensation, and by this regulate gene expression. The former is catalyzed by histone acetylases (HATs), and the latter by histone deacetylases (HDACs). The effects of their presence are upregulation and downregulation of gene expression, respectively. Whereas, in the case of methylation, the expression is regulated by histone methyltransferases (HMTs) and histone demethylases (HDMs) and their action depends on the site of the methylated residue as well as on the degree of methylation [20]. For example, histone H3 lysine 27 trimethylation (H3K27me3) decreases expression, while H3K4me2/3 activates transcription (Figure 1) [59]. Apart from these two modifications, there are also some studies exploring the crotonylation that occurs in individuals with MDD [60]. Histone crotonylation is based on adding the short-chain acyl groups to amino acids (aa) and is performed through the transfer of crotonyl groups by crotonyl-CoA. This modification mostly appears in colon and brain and results in the activation of transcription [61].
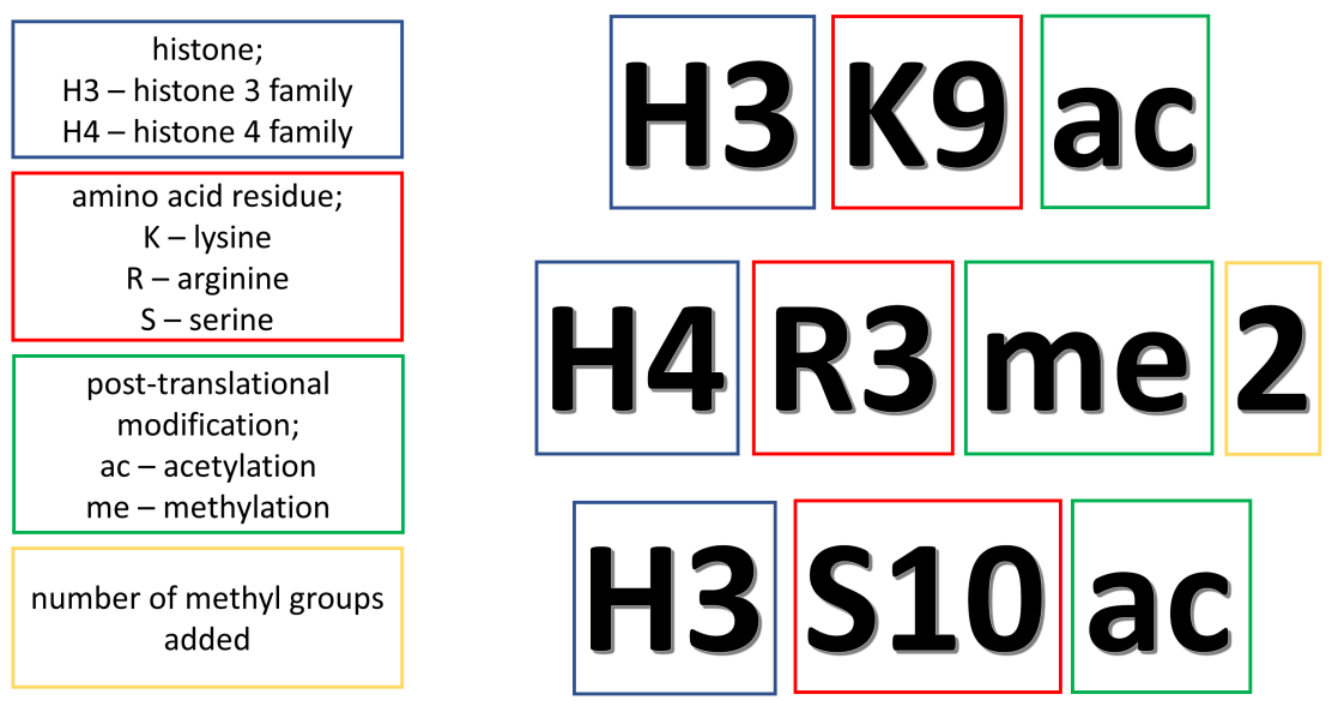

Figure 1. The explanation of abbreviations related to histone modifications.

The most frequent modifications discovered in depression are acetylation and methylation at the lysine residues, especially these of histone 3 or 4 [58]. These changes are remarked both in animal models of the disease and in patients with MDD. Due to this fact, these epigenetic modifications should be considered as the diagnostic markers of depression. However, this is not the only area where PTMs could play a great role. Recent studies prove that histone modifications may be also treated as targets in the treatment of depression. The examples show a significant effect of histone deacetylase inhibitors (HDACis) on the condition of MDD in clinical as well as in vivo studies. What is even more interesting is that the drugs currently administered to patients with depression, like selective serotonin reuptake inhibitors (SSRIs), were tested for their impact on PTMs, and the results have revealed significant post-treatment differences [20]. Herein, we present the results confirming the importance of PTMs in the diagnosis and treatment of depression. 


\subsection{Histone Modifications in the Diagnostics of Depression}

\subsubsection{Animal Models of Depression}

Due to the fact that MDD is an increasing problem in the modern society, it is worth expanding the diagnostic spectrum to better recognize the disease in patients. Furthermore, current diagnostic methods are based on questionnaires and surveys, which may not be sufficient to adequately determine the severity of the disease. Therefore, attention should be paid to PTMs, which are characteristic signs of depression. The epigenetic alterations have been studied mainly in animal models subjected to stress. An important question is whether the use of animal models in a research conducted on depression is effective. Although depression is a complex disease, symptoms such as anhedonia, behavioral despair, helplessness as well as changes in appetite and sleep patterns have been observed in animal models. These symptoms induced by models of stress form a depressive-like behavior.

In the case of studies performed on mouse models, we can observe that the pattern of PTMs depends on parts of the brain. In the research conducted on nucleus accumbens (NAc; a part of the reward circuitry) obtained from mice subjected to chronic stress one could observe: (i) decreased level of $\mathrm{H} 3$ acetylation, (ii) reduced levels of HDAC2 and 5, and (iii) reduced H3K14ac [62-64]. In addition to acetylation changes, there are methylation alterations in NAc. Here, methylation is regulated by G9a histone methyltransferase. Mice with genetically reduced G9a have an increased susceptibility to social defeat stress (SDS) [65]. Similarly to NAc, a decreased level of acetylation, i.e., H3K9ac, was observed in the hippocampus of mice subjected to SDS and decreased HDAC2 and 5 expression levels in the hippocampus after chronic restraint stress $[66,67]$. However, in the hippocampus, three weeks after the stress event there is a noticeable increase in acetylation in H4K12, an increase in HATs expression and a decrease in H3K4me3 [66]. As mentioned above, histone methylation exerts different effects, depending on the site of alteration. In this case, H3K4me3 is responsible for activating transcription [68]. Increased level of HATs and decreased level of HDACs are also observed in the cortex of mice after SDS [66]. Furthermore, SDS induces downregulation of BDNF and increases repressive histone methylation at $B D N F$ promoters in the mouse hippocampus [69]. Nonetheless, adolescent social stress reduces H3K9me2 in the mouse medial prefrontal cortex [70]. Moreover, chronic stress also leads to a reduced level of histone crotonylation and an upregulation of chromodomain Y-like protein (CDYL; histone methyllysine reader, inhibits the activity of the nerve growth factor VGF and synaptic plasticity) in a medial prefrontal cortex, being accompanied by an elevation of anhedonia and social avoidance behaviors [60]. Another histone modification can be also associated with depression-histone3-lysine9- $\beta$ hydroxybutyrylation, which is triggered by $\beta$-hydroxybutyrate (can be used by the brain as a source of energy with an insufficiency of glucose). The level of this modification was decreased in the brains of stressed mice [71].

The stress factors may have different impacts on epigenetic changes in individuals with varying degrees of susceptibility to stress. The BALB mice strain (a concatenation of Bagg and Albino), in comparison to the C57BL/6, is characterized by reduced adaptability to stress factors. It is caused by the behavior of BALB dams, i.e., they provide a lower level of maternal care, additionally having different levels of gamma-aminobutyric acid (GABA) receptor and c-Fos expression [72,73]. Predictably, decreased H3 acetylation, increased HDAC2, and decreased activating H3K4me3 methylation in the region of the glial cellderived neurotrophic factor ( $G d n f$; gene related to adaptation to chronic stress) promoters were observed in BALB mice. In C57BL/ 6 mice, only H3 acetylation was elevated and H3K27me3 decreased in the regions of Gndf promoters [74]. This methylation results in repressed transcription [68].

Especially interesting mice studies are those examining the effect of maternal separation on epigenetic alterations in offspring, due to introduction of depressive-like behavior. Interestingly, separation for a short period of time caused reduction in acetylation of $\mathrm{H} 3$ located in dopamine- and cAMP-regulated neuronal phosphoprotein (DARPP32) promoters, 
yet was not observed for long-term separation [75]. For middle-aged offspring, decreased expression of glucocorticoid receptor (GR) and decreased level of histone acetylation in the region of the GR promoters along with increased level of HDAC5 were observed. These changes became more pronounced in adult individuals [76]. It is curious that PTMs occur in a fetus when a mother is stressed and that the offspring of stressed pregnant mice show a depressive-like behavior. Furthermore, they have a decreased level of $B D N F$ expression, an increased level of HDAC1 and HDAC2, and the decreased level of H3K14ac in the region of $B D N F$ promoters in the hippocampus [63].

Studies conducted on rat models also present interesting results. In stressed rats, an elevated level of acetylation at H3, i.e., elevation of H3K18ac, can be observed in the medial prefrontal cortex [77], while in the hippocampus the level of H3 acetylation was decreased in the region of the $B D N F$ promoters [50]. Moreover, the characteristic feature of stressed rats is an increased HDAC5 expression in the hippocampus and prefrontal cortex [78,79]. Changes in acetylation status can be observed in several parts of the brain: (i) decreased level of H3K14, H3K23, H4K16 acetylation in the prefrontal cortex [79], (ii) decreased level of H3K9, H3K14, H3K23, H4K16 and H4K12 acetylation in the hippocampus, (iii) decreased level of H4K8ac and increased level of H3K18ac and H3K12ac in the ventral hippocampus and (iv) increased level of acetylation in $\mathrm{K} 9$ and $\mathrm{K} 14$ of $\mathrm{H} 3$ and K5, K8, K12, K16 of H4 in the dorsal raphe $[77,78]$.

Among the results of studies performed on rats, there are also noticeable changes in histone methylation. Rats exposed to chronic stress have decreased H3K9me3 in corticotrophin-releasing hormone receptor $1(\mathrm{Crhr} 1)$ promoters [80]. Stress leads to changes in dentate gyrus and hippocampus, i.e., increases the level of H3K4me3, decreases the level of H3K27me3 and H3K9me1, which elevates with prolonged stress and decreases the H3K9me3 only in dentate gyrus [81]. The effect of the first two methylations remains unknown, and the last one results in repressed transcription.

Epigenetic changes were also studied in Indian house crows that were stressed by artificial lights at night. In their hippocampus reduced $\mathrm{H} 3$ acetylation and increased HDAC4 expression were found in the region of the BDNF promoters [82].

\subsubsection{Clinical Trials in Depression}

PTM disturbances are characteristic for patients with MDD, and the results of studies with human participants are similar to these obtained in animal models. However, there are considerably fewer studies conducted on patients with depression than ones using animals. This is obvious due to the fact that patients' brains are not collected in the standard procedures, and can only be obtained from suicide victims with their family's consent. The obtained findings confirm elevated levels of HDAC2 and HDAC5 in the peripheral blood cells of depressive patients [83]. Furthermore, the increased level of HDAC5 is correlated with an increased expression of cyclic AMP-responsive element-binding protein 1 (CREB-binding protein), which is often a target in antidepressant therapy possessing histone acetyltransferase activity (to activate gene transcription) [84]. In the post-mortem studies, the methylation level in the prefrontal cortex of MDD patients was investigated. There was an increase in the transcriptionally repressing H3K9me3 in connexin 30 and 43 (CX30 and CX43; related to astrocyte communication) [85] and an increased level of transcriptionally activated H3K4me3 and an elevated synapsin-2 (SYN2) expression. Dysregulation of synapsin proteins is often associated with neuropsychiatric disorders [86]. The data collected in the above part of the review are presented in Table 3. 
Table 3. Studies reporting epigenetic alterations in the course of depression.

\begin{tabular}{|c|c|c|c|c|}
\hline $\begin{array}{c}\text { Histone } \\
\text { Modification }\end{array}$ & Material & Model of Depression/Patients & Results & Paper \\
\hline $\mathrm{H} 3 \mathrm{~K} 12 \mathrm{ac}$ & Ventral hippocampus & Chronic social defeat stress in rats & Increased level of acetylation & [77] \\
\hline \multirow[t]{5}{*}{ H3К14ac } & Nucleus accumbens & Social defeat stress in mice & Decreased level of acetylation & [64] \\
\hline & Hippocampus & $\begin{array}{c}\text { Gestational stress in offspring of } \\
\text { pregnant mice }\end{array}$ & Increased level of acetylation & [63] \\
\hline & Prefrontal cortex & Chronic unpredicted stress in rats & Decreased level of acetylation & [79] \\
\hline & Dorsal raphe & Chronic social defeat stress in rats & Increased level of acetylation & [77] \\
\hline & Hippocampus & Chronic unpredicted stress in rats & Decreased level of acetylation & [79] \\
\hline \multirow[t]{2}{*}{ H3К18ас } & Medial prefrontal cortex & Chronic social defeat stress in rats & Increased level of acetylation & [77] \\
\hline & Ventral hippocampus & Chronic social defeat stress in rats & Increased level of acetylation & [77] \\
\hline \multirow[t]{2}{*}{ Н3К23ас } & Prefrontal cortex & Chronic unpredicted stress in rats & Decreased level of acetylation & [79] \\
\hline & Hippocampus & Chronic unpredicted stress in rats & Decreased level of acetylation & [79] \\
\hline \multirow[t]{3}{*}{ H3K27me3 } & Ventral striatum & Chronic stress in C57BL/6 mice & Increased level of methylation & [74] \\
\hline & Hippocampus & Acute and restraint stress in rats & Decreased level of methylation & [81] \\
\hline & Dentate gyrus & Acute and restraint stress in rats & Decreased level of methylation & {$[81]$} \\
\hline \multirow[t]{4}{*}{ H3K4me3 } & Hippocampus & Social defeat stress in mice & Decreased level of methylation & {$[66]$} \\
\hline & Ventral striatum & Chronic stress in BALB mice & Decreased level of methylation & [74] \\
\hline & Hippocampus & Restraint stress in rats & Decreased level of methylation & [81] \\
\hline & Prefrontal cortex & MDD suicide victims & Increased level of methylation & [86] \\
\hline \multirow[t]{3}{*}{ Н3К9ас } & Hippocampus & Social defeat stress in mice & Decreased level of acetylation & [66] \\
\hline & Hippocampus & Chronic unpredicted stress in rats & Decreased level of acetylation & [78] \\
\hline & Dorsal raphe & Chronic social defeat stress in rats & Increased level of acetylation & [77] \\
\hline \multirow[t]{2}{*}{ H3K9me1 } & Hippocampus & Acute stress in rats & Decreased level of methylation & [81] \\
\hline & Dentate gyrus & Acute stress in rats & Decreased level of methylation & [81] \\
\hline H3K9me2 & Medial prefrontal cortex & Adolescent social stress in mice & Decreased level of methylation & [70] \\
\hline \multirow[t]{3}{*}{ H3K9me3 } & Hypothalamus & Chronic unpredictable mild stress in rats & Decreased level of methylation & [80] \\
\hline & Dentate gyrus & Chronic restraint stress in rats & Decreased level of methylation & [81] \\
\hline & Prefrontal cortex & MDD suicide victims & Increased level of methylation & [85] \\
\hline \multirow[t]{4}{*}{$\mathrm{H} 4 \mathrm{~K} 12 \mathrm{ac}$} & Hippocampus & Social defeat stress in mice & Increased level of acetylation & {$[66]$} \\
\hline & Ventral hippocampus & Chronic social defeat stress in rats & Decreased level of acetylation & [77] \\
\hline & Hippocampus & Chronic unpredicted stress in rats & Decreased level of acetylation & [78] \\
\hline & Dorsal raphe & Chronic social defeat stress in rats & Increased level of acetylation & [77] \\
\hline \multirow[t]{3}{*}{$\mathrm{H} 4 \mathrm{~K} 16 \mathrm{ac}$} & Prefrontal cortex & Chronic unpredicted stress in rats & Decreased level of acetylation & [79] \\
\hline & Hippocampus & Chronic unpredicted stress in rats & Decreased level of acetylation & [79] \\
\hline & Dorsal raphe & Chronic social defeat stress in rats & Increased level of acetylation & [77] \\
\hline $\mathrm{H} 4 \mathrm{~K} 5 \mathrm{ac}$ & Dorsal raphe & Chronic social defeat stress in rats & Increased level of acetylation & [77] \\
\hline \multirow[t]{2}{*}{ H4K8ac } & Ventral hippocampus & Chronic social defeat stress in rats & Decreased level of acetylation & [77] \\
\hline & Dorsal raphe & Chronic social defeat stress in rats & Increased level of acetylation & [77] \\
\hline
\end{tabular}

ac-acetylation, MDD—major depressive disorder, me-methylation.

\subsection{Histone Modifications in the Treatment of Depression}

\subsubsection{Animal Models of Depression}

Histone modifications can be used not only in the diagnosis of depression, but also as a therapeutic target. Often, medications that are used in the MDD therapy have a significant impact on the PTMs of histones.

In the studies carried out on mice models of depression, HDACis were the most frequently tested compounds. They inhibit the action of histone deacetylases, which results in an increased level of acetylation. The effect of elevation of histone acetylation facilitates gene transcription. The researchers confirmed that studied HDACis, crebinostat and neurinostat, inhibited the activity of HDAC1, 2, 3, 6 and 8 in CREB-reporter cells, and caused the elevation of acetylation of $\mathrm{H} 3$ and $\mathrm{H} 4$ in cultured mouse primary neurons. In addition, HDACis are able to reduce the level of depressive-like behavior. In stressed mice treated with belinostat, which is also an HDACi, a significant decrease in the level of immobility was observed in the tail suspension test [87-89]. Another well-known HDACi, sodium butyrate $(\mathrm{NaB})$, was also found to have an antidepressant effect. In mice in which stress was induced with lipopolysaccharide (LPS) and in those with chronic restraint stress, 
it was observed that acute $\mathrm{NaB}$ administration reduced the depressive-like behavior $[67,90]$. $\mathrm{NaB}$ is also able to lower immobility scores in the tail suspension test and in the forced-swim test $[91,92]$. When it comes to a molecular analysis of mice brains, acute $\mathrm{NaB}$ administration increased $\mathrm{H} 4$ acetylation in the hippocampus, while chronic treatment decreased it [91]. In addition, systemic injection of $\mathrm{NaB}$ increased $B D N F$ expression in the frontal cortex and hippocampus. Moreover, $\mathrm{NaB}$ increased $\mathrm{H} 3$ and $\mathrm{H} 4$ acetylation in the hippocampus and H3ac in the frontal cortex $[67,92]$. Considering another HDACi, MS-275, it also exerts an antidepressant effect. Infusion of this inhibitor into the hippocampus, amygdala or NAc results in a reduction of depressive-like behavior $[64,93]$. However, there is a study where chronic treatment with valproic acid (HDACi) did not show significant differences in the expression of HDAC2 and 5 or HDAC4, 6 and 8 in the mice leukocytes [83].

Due to the potential for using PTMs in the fight against depression, it is almost obvious to evaluate currently used antidepressants in the context of their effect on histone modifications. In studies with imipramine, a tricyclic antidepressant, it was confirmed that it reversed changes in $\mathrm{H} 3$ methylation induced by SDS in NAc in mice [94]. Additionally, chronic imipramine treatment resulted in decreasing histone methylation, an increase of histone acetylation at $B D N F$ promoters and downregulation of HDAC5 in the hippocampus [69]. In contrast, in mice treated with fluoxetine (SSRI) an increased level of H4K12ac was observed [95].

When it comes to the studies conducted on rat models of depression, there are numerous pieces of evidence of the antidepressant effect of HDACi. NaB caused reduced immobility on the forced-swim test and the tail suspension test, and an increase in acetylation of H4 in the hippocampus of stressed rats [96,97]. MS-275 had a similar effect in rats as in mice, and when administered chronically, it showed a reduction in immobility in the forced-swim test and the tail suspension test. The antidepressant effect was accompanied by an increase in $\mathrm{H} 3$ acetylation and an elevated CREB and BDNF level in the ventrolateral orbital cortex of stressed rats [98]. Another example, vorinostat, reversed depressive-like behavior in rats with chronic alcohol consumption and raised their H3K9ac levels [99].

Fluoxetine, escitalopram and venlafaxine were among the SSRIs tested in rat models in order to evaluate whether they could improve depression severity levels. Rats subjected to chronic stress had an increase in $\mathrm{H} 3 \mathrm{~K} 9 \mathrm{me} 3$ in dentate gyrus (DG) after fluoxetine treatment and an increase in $\mathrm{H} 3$ acetylation with escitalopram $[81,100]$. In the case of venlafaxine, it stopped the increase in HDAC5 expression and the decrease in acH3K9 that occurred after stress in rats [101].

Nevertheless, interesting studies on rat models examined, instead of the effect of chemical molecules on changes in histones, the relationship of PTMs in depression and treatment with methods such as acupuncture and electroconvulsive seizures. The former reversed the upregulation of HDAC2 in the hippocampus, which has appeared after chronic unpredicted mild stress in rats [102]. Rats that underwent electroconvulsive seizures had elevated levels of acetylation in $\mathrm{H} 4$ in the hippocampus within the BDNF and CREB promoters immediately after surgery, and two hours later the increase in $\mathrm{H} 4$ acetylation was accompanied by the decrease in acetylation in $\mathrm{H} 3$ [103].

A huge number of studies reflect a great interest in the area of PTMs in depression, and the above results demonstrate how important the relationship between histone modification and depression pathophysiology is.

\subsubsection{Clinical Trials in Depression}

Unfortunately, there are still few clinical trials investigating the link between PTMs and depression. So far only two studies focused on evaluating the impact of SSRIs. Each study was conducted in a group of patients with diagnosed MDD. Citalopram from the SSRI group was used in a group of 25 patients and its effect on histone methylation was examined. A decrease in H3K27me3 in blood was observed as a result of the treatment and a negative correlation between the methylation and the depression severity was shown. 
This confirms the relationship of histone modification with depression that was discovered in animal models [104].

A group of 48 patients was treated with other drugs belonging to SSRIs, fluoxetine or paroxetine (NCT01182103). The treatment caused a slight increase in the level of acetylation in $\mathrm{H} 3$ and $\mathrm{H} 4$ within the BDNF promoters. This allows to suggest that the use of histone modifications as a therapeutic target has a great potential.

Interestingly, 234 patients were treated (NCT01912196) with S-adenosyl methionine (MSI-195), which is the methyl-donating substrate of histone methyltransferases. The drug was given alongside ongoing antidepressant medication. Although no significant differences in the effect of this drug were found in relation to the depression severity scales (HamD17, MADRS, IDS-SR30) in comparison to the placebo group [105], the authors indicated that the test scores were better in the tested group than the placebo group in the first phase of the study. Moreover, the group from the second phase was demographically and clinically different, which could have contributed to the general lack of significant statistical differences. This confirms that there is a need for an individual approach for patients with MDD and that current treatment is insufficient and should be extended in order to help anyone with depression.

The data presented in this part of review are totaled in Table 4.

Table 4. Studies reporting the impact of treatment on histone modifications and histone deacetylases (HDAC) in depression.

\begin{tabular}{|c|c|c|c|c|}
\hline Treatment & Material & Model of Depression/Patients & Results & Paper \\
\hline \multicolumn{5}{|c|}{ Histone deacetylase inhibitors } \\
\hline Crebinostat & Primary neurons & Mice & $\begin{array}{c}\text { Inhibition of the activity of HDAC1, 2, 3, } 6 \text { and } 8 \text { and } \\
\text { elevation of } \mathrm{H} 3 \mathrm{ac} \text { and } \mathrm{H} 4 \mathrm{ac}\end{array}$ & [87] \\
\hline \multirow{5}{*}{$\begin{array}{l}\text { Ms-275 } \\
\text { Neurinostat } \\
\text { Sodium } \\
\text { butyrate }\end{array}$} & Ventrolateral orbital cortex & Social defeat stress in rats & Increase in $\mathrm{H} 3 \mathrm{ac}$ & [98] \\
\hline & Primary neurons & Mice & Inhibition of the activity of HDAC1, 2, 3 & [88] \\
\hline & Hippocampus & Acute or chronic stress in mice & $\begin{array}{c}\text { Increase in } \mathrm{H} 4 \text { ac after acute administration, but decrease } \\
\text { after chronic treatment }\end{array}$ & {$[91]$} \\
\hline & Hippocampus and frontal cortex & Chronic restraint stress in mice & $\begin{array}{c}\text { Increase in } \mathrm{H} 3 \mathrm{ac} \text { and } \mathrm{H} 4 \mathrm{ac} \text { in the hippocampus and } \mathrm{H} 3 \mathrm{ac} \\
\text { in the frontal cortex }\end{array}$ & {$[92]$} \\
\hline & Hippocampus & Chronic variable stress in rats & Increase in $\mathrm{H} 4 \mathrm{~K} 12 \mathrm{ac}$ & [96] \\
\hline \multicolumn{5}{|c|}{ Selective serotonin reuptake inhibitors } \\
\hline Citalopram & Blood & MDD patients & Decrease in H3K27me3 & [104] \\
\hline Escitalopram & Hippocampus & Maternal separation in rats & Increase in $\mathrm{H} 3 \mathrm{ac}$ & {$[100]$} \\
\hline \multirow[t]{2}{*}{ Fluoxetine } & Forebrain neocortex & Infant maternal separation in mice & \multirow{3}{*}{$\begin{array}{c}\text { Increase in H4K12ac } \\
\text { Increase in H3K9me3 } \\
\text { Inhibition of HDAC5 expression, increase and decrease in } \\
\text { H3K9ac }\end{array}$} & {$[95]$} \\
\hline & Dentate gyrus & Chronic restraint stress in rats & & [81] \\
\hline Venlafaxine & Hippocampus & Chronic unpredicted stress in rats & & {$[101]$} \\
\hline \multicolumn{5}{|c|}{ Tricyclic antidepressants } \\
\hline \multirow[t]{2}{*}{ Imipramine } & Nucleus accumbens & Social defeat in mice & Reversed changes in $\mathrm{H} 3 m e$ triggered by stress & [94] \\
\hline & Hippocampus & Chronic social defeat stress in mice & $\begin{array}{l}\text { Decrease in H3K4me2, increase in histone acetylation at } \\
\text { BDNF promoters and downregulation of HDAC5 }\end{array}$ & {$[69]$} \\
\hline
\end{tabular}

ac - acetylation, HDAC — histone deacetylase, MDD—-major depressive disorder, me — methylation.

\section{4. miRNA}

Epigenetics associated with small non-coding RNAs are most spectacularly developed in the context of miRNAs, while a large body of evidence suggests an impact of their interference on a plethora of biological phenomena [106]. They are short, about 21-nucleotide long, single-stranded RNAs that use mainly two mechanisms of post-transcriptional gene silencing (PTGS). Namely, they either cause degradation of the transcript or disrupt the process of translation, both of which are placed in cytoplasm. However, recently it was found that miRNAs are also present in the nucleus, where they are involved in both repression and activation of transcription [10]. To perform their tasks, they need to undergo a multistep process of maturation, initialized with a transcription of long primary miRNAs (pri-miRNAs) by RNA polymerases II or III. Then, pri-miRNAs are shortened to 70-nuclotide long precursor miRNAs (pre-miRNAs) by a Microprocessor complex consisting of RNase III enzyme Drosha and a double-stranded RNA-binding protein, Di George syndrome critical region 8 gene (DGCR8), followed by creation of double-stranded miRNA duplexes (ds-miRNAs) by additional activity of Dicer. Aside from Dicer, ds-miRNAs asso- 
ciate with Argonaute (Ago) and trans-activation response RNA-binding protein (TRBP) forming the RNA-inducing silencing complex (RISC) in cytoplasm, while the final step involves degradation of one of the RNA strands to form a working miRISC complex. Interestingly, the complex can also be constituted of only Ago and miRNA molecule; then it is called minimal RISC complex. The canonical mechanism of RNA interference in cytoplasm is well-established and is achieved by creating Watson-Crick hydrogen bonds between positions from 2 to 8 of miRNA $5^{\prime}$ end (the so-called seed region) and miRNA response element (MRE) located in most cases in $3^{\prime}$ untranslated region ( $3^{\prime}$-UTR) and rarely in $5^{\prime}$-UTR or coding region of transcript [107-110]. However, in the case of $\sim 15-80 \%$ of miRNAs, these interactions can be established through non-canonical mechanisms [111,112]. While their role in the nucleus is not fully understood yet, two main mechanisms have been established, i.e., PTGS mediated by nuclear RISC for miRNAs and other endonuclear non-coding RNAs and direct interactions with the promoters, where the resulting down- or upregulation depends on location and methylation status of target sides $[113,114]$. For the latter, three mechanisms have been proposed: (i) RNA-RNA model, where direct interaction of minimal RISC with the transcript resulting from recruitment of histone modifiers [115-118], (ii) RNA-DNA hybrid model, in which Ago is guided by miRNA to the TATA box or binding sites of transcription factors (TFs) triggering recruitment of histone modifiers or TFs [119-123] and (iii) RNA-DNA triplex model, where topology of DNA is changed due to binding of miRNA to major groove using Hoogsteen or reverse Hoogsteen bonds, which recruit TFs [124,125].

Through those mechanisms one miRNA molecule can influence expression of hundreds of target genes, thus, together they have an enormous impact on transcriptome and proteome [10]. It is then not surprising that changes of their expression have been found to be involved in etiopathogenesis of many disorders, including cancers, diabetes [126], neurodegenerations and neuropsychiatric ones [127-129]. This is also true for depression, where in the last decade several dozen miRNAs have been found to be deregulated. However, there is a debate surrounding the consistency of the results obtained in different studies [130]. The establishment of such a panel of peripheral biomarkers is especially important, since the collection of a blood sample is relatively harmless for the patient and the detection of miRNA in plasma or serum is not challenging [131].

\section{1. miRNAs and the Brain-A Link between Neuroplasticity and Depression}

It has been found that miRNAs are highly expressed in brain tissue, where they play multiple roles, mostly in nervous system development, but also in the regulation of neuronal and synaptic plasticity [132-135]. Not surprisingly, disturbances in brain plasticity were also found to be involved in the pathogenesis of depression $[7,136]$. Several studies done on post-mortem brains of depressed patients or animal models of depression showed reduction of the prefrontal cortex (PFC) and hippocampus volumes, neuronal atrophy, decreased length and branching of dendrites, etc. [137-140]. Interestingly, antidepressant treatment seems to reverse these processes, since in preclinical studies using stressedinduced depression-like behavior, chronic, but not acute, administration of antidepressants caused neurogenesis in the hippocampus, which was further confirmed in post-mortem hippocampal cells of treated depressed patients [141-145]. Here, the working hypothesis is that disturbances of neuroplasticity affect homeostatic control of synaptic connections and the ability of individuals to cope with stressful life events, thus causing depression to emerge [146].

Indirect evidence of miRNA involvement in synaptic plasticity was gathered using Dicer knockout mice. These animals showed microcephaly, reduced dendritic branch elaboration, increased length of dendritic spine but without increase of spine density, while specific to only Purkinje cells, knockout resulted in the death of those cells and ataxia [147,148]. Furthermore, in another study, a knockout of DGCR8 affected cognitive performance and caused neuronal deficiency in mice [149]. All those results indicated the importance of miRNAs in proper functioning of nervous tissue. Indeed, up to date, several 
candidates have been proposed, i.e., miR-9, miR-16, miR-124, miR-125b, miR-132, miR-134 and miR-138 [131]. Some of them are tightly linked, i.e., they regulate or are regulated by proteins involved in neuroplasticity-BDNF, CREB (cAMP response element-binding protein), and SIRT1 (Sirtuin 1). Among these proteins, BDNF is one of the key factors that play a pivotal role in neuroplasticity. Moreover, it is also crucial in neuroinflammation, thus making it the perfect candidate that can bridge both neurogenic and inflammatory hypotheses of depression [150].

\subsection{Circulating miRNAs as Biomarkers of Depression}

\subsubsection{Blood, Plasma and Serum miRNAs as Biomarkers of Depression}

As aforementioned, the use of circulating miRNA molecules as peripheral markers seems tempting, especially considering the ease of collecting the material and performing tests. Furthermore, the diagnostic potential of individual serum miRNAs, e.g., miR34a-5p, let-7d-3p, miR-221-3p, miR-451-a, was evaluated as high via receiver operating characteristic (ROC) curve analyses [151]. The same statistical approach also indicated that rather than single molecules, a panel of miRNAs (e.g., miR-4743, -26b, -1972, -4498, -4485 examined in PBMCs) could serve as a tool for MDD diagnosis [152]. However, a recent review by Yuan et al. found that there is little replication across the studies [130]. Authors identified 23 clinical studies and six performed using the animal models, which discovered 178 dysregulated miRNAs. Unfortunately, results for only two of them were replicated, i.e., miR-132 in four studies and miR-16 in two preclinical studies. Interestingly, the former molecule is tightly connected to neuroplasticity through BDNF [153], while the latter is involved in the regulation of serotonin transporter (SERT) and is thought to be implicated in the mechanism of fluoxetine, belonging to the SSRI antidepressant class, where it mediates neurogenesis in the hippocampus [154,155]. Moreover, miR-16 was found to be reduced in depressed patients' cerebrospinal fluid (CSF), but not in blood, and when rats were treated with anti-miR-16 they exhibited depression-like behaviors, as well as increased levels of CSF serotonin and raphe nuclei SERT [156]. Even more interestingly, rats resilient to the CNS procedure had elevated serum levels of miR-16 [157]. This could indicate a link between circulating miRNAs and the ones present in the CNS. However, such regularity has not been yet observed in clinical studies and the mechanism of such a relationship remains elusive. Nevertheless, Yuan et al. placed guidelines in their review for the future research in this topic to improve replicability of the results from study to study [130].

\subsubsection{Cerebrospinal Fluid miRNA as a Biomarker of Depression}

Although collection of CSF is not as easy as collection of blood, it is thought to better represent fluctuations in miRNAs status than peripheral tissue or even post-mortem brain samples [158,159]. Its close interaction with the brain makes CSF an ideal candidate for study changes in the CNS $[160,161]$. Moreover, CSF-derived markers should have superior sensitivity, specifically when compared to blood ones, as it was shown in the meta-analysis of CNS cancers [162]. This statement seems to be also true for depression, since in the study mentioned earlier expression of miR-16 in CSF, but not in blood, was lower in depressed patients when compared to healthy subjects and was positively correlated with the amount of serotonin [156]. Another report that compared serum and CSF miRNAs in depressed patients found that from 16 deregulated miRNAs in CSF only four were also deregulated in serum [151]. Although these results are promising, there is too little research to predict whether CSF-derived miRNAs could be superior markers of the disease.

\section{3. miRNAs and Depression Therapy}

Treatment of the depression seems to be especially challenging. Although many substances with antidepressant properties have been developed over the years and a plethora of drugs is now available, still about $1 / 3$ of the patients do not respond to traditional pharmacotherapy [163]. Moreover, proper evolution of the patients' response to treatment 
can be performed only after six weeks of therapy. It is therefore not surprising that markers are sought to enable an earlier evaluation of the effectiveness of therapy. Since miRNA concentration can rapidly change in order to compensate for changes in environment [164], they seem to be perfect candidates for such markers [165]. Indeed, a great body of evidence was provided by clinical, preclinical and in vitro studies showing that changes of miRNA expression can reflect the progress of depression treatment (Table 5) [159].

Table 5. Summary of studies reporting evidence of miRNA involvement in treatment response.

\begin{tabular}{|c|c|c|c|c|}
\hline Treatment & Model/Patients & $\begin{array}{l}\text { Type of Biological } \\
\text { Material }\end{array}$ & Results/Findings & Paper \\
\hline \multicolumn{5}{|c|}{ Selective serotonin reuptake inhibitors (SSRIs) } \\
\hline Fluoxetine & $\begin{array}{l}\text { Mice infused with antidepressant into } \\
\text { raphe nuclei }\end{array}$ & Raphe nuclei & $\begin{array}{l}\text { Fluoxetine infusion caused overexpression of miR-16, which resulted in } \\
\text { reduction of SERT expression. }\end{array}$ & [154] \\
\hline \multirow{8}{*}{ Paroxetine } & MS in Sprague Dawley rat & Hippocampi & $\begin{array}{l}\text { MS reduced expression of miR-451, while fluoxetine treatment reversed } \\
\text { this change. }\end{array}$ & [166] \\
\hline & $\begin{array}{l}\text { SK-N-SH and SH-SY5Y neuroblastoma } \\
\text { cell lines }\end{array}$ & Cell lysates & $\begin{array}{l}\text { Fluoxetine increased expression of miR-572 and miR-663a, which are } \\
\text { involved in fundamental neurodevelopmental processes. }\end{array}$ & [167] \\
\hline & $\begin{array}{l}\text { Genetically modified mouse models, } \\
\text { expressing higher or lower levels of } \\
\text { miR135; chronic social defeat model }\end{array}$ & Raphe nuclei & $\begin{array}{c}\text { Mice overexpressing miR-135 were resilient to social defeat, while } \\
\text { knockout induced anxiety-like behaviors and decreased the response to } \\
\text { antidepressants. }\end{array}$ & [168] \\
\hline & PTSD in mice & Prefrontal cortices & Reduction of miR-1971 expression after administration of fluoxetine. & [169] \\
\hline & 1C11 neuroectodermal cell line & Cell lysates & $\begin{array}{l}\text { miR-16 overexpression resulted in reduction of SERT translation and } \\
{\left[{ }^{3} \mathrm{H}\right] \text {-paroxetine binding sides. }}\end{array}$ & [154] \\
\hline & $\begin{array}{l}\text { U87 human glioblastoma-astrocytoma } \\
\text { cell line }\end{array}$ & Cell lysates & $\begin{array}{c}\text { Treatment with paroxetine induced expression of BDNF and was } \\
\text { limited by upregulation of miR-30a-5p. }\end{array}$ & [170] \\
\hline & $\begin{array}{l}80 \text { human LCLs form healthy adult } \\
\text { females }\end{array}$ & Cell lysates & Paroxetine-sensitive LCLs overexpressed miR-151-3p. & [171] \\
\hline & $\begin{array}{l}84 \text { depressed patients and } 78 \text { control } \\
\text { volunteers }\end{array}$ & Serum & $\begin{array}{l}\text { Eight-week treatment resulted in increased miRNA-451a levels, } \\
\text { decreased miRNA-34a-5p and miRNA-221-3p levels and reduced } \\
\text { HAM-D scores. }\end{array}$ & [172] \\
\hline \multirow[t]{2}{*}{ Citalopram } & $\begin{array}{l}32 \text { depressed patients, classified into } \\
\text { remitters and non-responders, based } \\
\text { on changes in HAM-D scores, and } 18 \\
\text { controls }\end{array}$ & Blood & $\begin{array}{l}\text { Downregulation of miR-1202 at baseline was found in remitters, when } \\
\text { compared to non-responders and controls; eight-week citalopram } \\
\text { administration upregulated miR-1202 only in remitters. }\end{array}$ & [173] \\
\hline & $\begin{array}{l}45 \text { untreated depressed patients, } 32 \\
\text { treated with citalopram and } 32 \text { healthy } \\
\text { volunteers }\end{array}$ & Plasma & $\begin{array}{l}\text { miR-132 was upregulated in untreated depressed patients, when } \\
\text { compared to healthy controls and citalopram-treated patients; and its } \\
\text { expression decreased after two-month citalopram administration, while } \\
\text { at the same time miR-124 expression increased. }\end{array}$ & [174] \\
\hline \multirow[t]{3}{*}{ Escitalopram } & MS and CUS in Sprague Dawley rats & NAc and striatum & $\begin{array}{c}\text { Escitalopram normalized increased expression of miR-326 after MS and } \\
\text { CUS. }\end{array}$ & [175] \\
\hline & 10 depressed patients & Blood & $\begin{array}{c}\text { Treatment significantly altered expression of } 30 \text { miRNAs: } 28 \text { were } \\
\text { upregulated, while two were downregulated. }\end{array}$ & [176] \\
\hline & 158 depressed patients & Blood & $\begin{array}{c}\text { Downregulation of miR-146a-5p, miR-146b-5p and miR-24-3p after } \\
\text { eight-week treatment with escitalopram }\end{array}$ & [177] \\
\hline \multicolumn{5}{|c|}{ Serotonin-norepinephrine reuptake inhibitors (SNRIs) } \\
\hline Duloxetine & Kunming mice in CUMS & $\begin{array}{l}\text { Hippocampi and } \\
\text { frontal lobes }\end{array}$ & $\begin{array}{l}\text { Three-week administration of duloxetine caused increased expression of } \\
\text { miR-18a, and miR-132 in hippocampus, while miR-134 and miR-124a } \\
\text { were downregulated; only miR-18 was upregulated in frontal lobe. }\end{array}$ & [178] \\
\hline & 258 depressed patients & Blood & $\begin{array}{l}16 \text { miRNAs changed specifically according to duloxetine treatment, } \\
\text { while miR-146a-5p, miR-146b-5p, miR-24-3p, miR-425-3p and } \\
\text { miR-3074-5p were all downregulated and strongly correlated. }\end{array}$ & [177] \\
\hline Desvenlafaxine & 20 depressed patients & Blood & $\begin{array}{c}\text { Using MRI miR-1202 levels were correlated with changes in brain } \\
\text { activity and connectivity occurring during an eight-week } \\
\text { antidepressant treatment. }\end{array}$ & [179] \\
\hline \multicolumn{5}{|c|}{ Miscellaneous } \\
\hline $\begin{array}{l}\text { Imipramine } \\
\text { (TCA) }\end{array}$ & Mice in CSDS & Blood & $\begin{array}{l}\text { Administration of imipramine downregulated } \mathbf{m i R}-146 \mathrm{~b}-5 \mathrm{p}, \mathrm{miR}-\mathbf{2 4}-3 \mathrm{p} \\
\text { and miR-425, while no differences were detected in the non-responders } \\
\text { or saline control groups. }\end{array}$ & [177] \\
\hline \multirow[t]{2}{*}{ Ketamine } & MS in Sprague Dawley rats & Hippocampi & Upregulation of $\mathbf{m i R}-598-5 \mathrm{p}$ after treatment. & [166] \\
\hline & Sprague Dawley rats & Hippocampi & $\begin{array}{l}\text { Three injections of ketamine once per day caused downregulation of } \\
\text { miR-206, while increase of BDNF level. }\end{array}$ & {$[180]$} \\
\hline \multirow[t]{4}{*}{ ECT } & MS in Sprague Dawley rats & Hippocampi & Upregulation of miR-598-5p after treatment. & [166] \\
\hline & ECS in Sprague Dawley rats & Blood and brains & $\begin{array}{l}\text { Chronic and acute ECS upregulated miR-212 in dentate gyrus, while } \\
\text { only chronic ECS increased level of this molecule in blood. }\end{array}$ & [181] \\
\hline & $\begin{array}{l}37 \text { depressed patients and } 34 \text { healthy } \\
\text { controls }\end{array}$ & Blood & $\begin{array}{l}\text { Elevated levels of miR-126-3p and miR-106a-5p were normalized after } \\
\text { ECT. }\end{array}$ & [182] \\
\hline & $\begin{array}{l}24 \text { TRD depressed patients and } 20 \\
\text { healthy controls }\end{array}$ & Blood & $\begin{array}{c}\text { miR-let-7b and miR-let-7c were downregulated after treatment as } \\
\text { compared to the controls. }\end{array}$ & [183] \\
\hline
\end{tabular}


Table 5. Cont.

\begin{tabular}{|c|c|c|c|c|}
\hline Treatment & Model/Patients & $\begin{array}{c}\text { Type of Biological } \\
\text { Material }\end{array}$ & Results/Findings & Paper \\
\hline CBT & 24 depressed patients & Blood & $\begin{array}{c}\text { Significantly higher levels of miR-135a after } 12 \text { weeks of CTB, when } \\
\text { compared to the same patients before therapy and with population } \\
\text { treated with SSRIs. }\end{array}$ & [168] \\
\hline \multirow[t]{2}{*}{$\begin{array}{l}\text { Different } \\
\text { antidepres- } \\
\text { sants }\end{array}$} & $\begin{array}{l}68 \text { patients treated with escitalopram } \\
\text { (SSRI) or nortriptyline (TCA) }\end{array}$ & Blood & $\begin{array}{l}\text { Downregulation of miR-146a-5p, miR-146b-5p, miR-24-3p and } \\
\text { miR-425-3p after treatment. }\end{array}$ & [177] \\
\hline & 32 depressed patients & PBMCs & $\begin{array}{c}\text { Significantly increased level of miR-124 in depressed patients as } \\
\text { compared to the healthy controls being decreased after eight-week } \\
\text { antidepressant treatment. }\end{array}$ & [184] \\
\hline
\end{tabular}

SERT—serotonin transporter; MS—maternal separation; LCLs-human lymphoblastoid cell lines; CBT-cognitive behavioral therapy; CUS — chronic unpredictable stress; NAc_-nucleus accumbens; CUMS—chronic unpredictable mild stress; MRI-magnetic resonance imaging; CSDS—chronic social defeat stress; PBMCs—peripheral blood mononuclear cells; TRD—treatment-resistant depression; HAM-D_ 24-item Hamilton Depression Scale; ECS—electroconvulsive stimulation.

\subsubsection{SSRI}

In an earlier mentioned study, fluoxetine increased miR-16 levels in serotonergic raphe nuclei, which resulted in downregulation of SERT [154]. Moreover, the same antidepressant was shown to upregulate two miRNAs, i.e., miR-451 and miR-598-5p, that were repressed in the hippocampus of mice that underwent maternal separation (MS) procedure [166]. Further evidence was introduced by in vitro studies, where two neuroblastoma cell lines, i.e., SK-NSH and SH-SY5Y, showed consistent overexpression of miR-572 and miR-663a after treatment with fluoxetine [167]. Another antidepressant belonging to the SSRI class, paroxetine, was also studied in vitro, where in human glioblastoma-astrocytoma cell line U87 it increased expression of BDNF and its transcriptional inhibitor miR-30a-5p [170]. Moreover, overexpression of miR-151-3p was found in human lymphoblastoid cell lines (LCLs), which were sensitive to this antidepressant [171]. Even more interestingly, patients that responded to the treatment with paroxetine exhibited increased miR-451a and decreased miR-34a-5p and miR-221-3p serum expression, while these molecules were correlated with the severity of the disease measured by the 24-item Hamilton Depression Scale (HAM-D) [172]. Similar results were obtained for blood levels of miR-1202, when treatment-naïve patients were treated with citalopram [173]. After the therapy using this SSRI class antidepressant, they were divided into two groups: remitters (REMs) and nonresponders (NRES) using HAM-D scores, and it was revealed that: (i) the former group had lower expression than NRES and control groups, (ii) no differences were found between the latter group and healthy individuals, and (iii) negative correlation was present between change in depression severity and expression of miR-1202. In another clinical study, it was shown that citalopram induced changes in serum expression of two miRNAs, i.e., miR-132 was upregulated, while miR-124 was downregulated [174]. Particularly interesting results were also found in relation to (S)-stereoisomer of citalopram-escitalopram. It was revealed that chronic unpredictable stress (CUMS), which induces depression-like behaviors in rats, caused upregulation of miR-326 in the nucleus accumbens and its downregulation in the striatum, while administration of escitalopram normalized it [175]. On the other hand, the antidepressant had no effect on another deregulated molecule-miR-9. Impressively, in depressed patients, 12-week escitalopram administration changed the expression of 30 miRNAs, and after target gene prediction and functional annotation analysis, they were revealed to be involved in pathways associated with neuronal brain function [176].

\subsubsection{SNRIs and TCA}

Another class of antidepressants-SNRIs-were also found to influence miRNA expression. One of them, desvenlafaxine, similarly to citalopram, influenced expression of miR-1202 in depressed patients [179]. Authors using functional magnetic resonance imaging (fMRI) and spectroscopy to detect glutamate showed that the level of this molecule was correlated with brain activity and connectivity throughout the treatment, and since miR-1202 was also correlated with glutamate, it was speculated that its mechanism of modulating antidepressant treatment outcome could involve changes in the glutamatergic 
system. Another SNRI, duloxetine, was found to upregulate miR-132 in the hippocampus and miR-18a in the hippocampus and frontal lobe, while downregulating hippocampal expression of miR-134 and miR-124a in mice exposed to CUMS [178]. This could indicate that this antidepressant targets primarily the hippocampus, and to a less extent the frontal lobe, where it deregulates miRNA expression. Duloxetine was also investigated in a clinical study, where it downregulated miR-146a-5p, miR-146b-5p, miR-24-3p and miR-425-3p in 516 samples of peripheral blood from depressed patients after antidepressant treatment vs. the same patients before treatment [177]. Moreover, authors replicated the results in two independent cohorts (apart from miR-425-3p, which was not downregulated in the second cohort) treated with either escitalopram or nortriptyline, which is a tricyclic antidepressant (TCA). Even more compelling, in the same paper three out of four miRNAs, i.e., miR-146b-5p, miR-24-3p and miR-425, were also downregulated when peripheral blood samples of mice exposed to the chronic social defeat stress (CSDS) before and after administration of imipramine belonging to the TCAs were compared. Lastly, these molecules were upregulated in post-mortem samples of the ventrolateral prefrontal cortex (vPFC) of suicidal depressed individuals when compared to psychiatrically healthy controls. Interestingly, these miRNAs are involved in regulating MAPK and Wnt signaling pathways, which link them to, among others, BDNF [177]. Another two clinical studies that used more than one antidepressant showed changes in miRNA in the peripheral blood of treated patients $[184,185]$. However, the set of altered miRNAs differed between studies. Since these three studies were conducted on different ethnic groups, i.e., populations of Canada, China and France, it could indicate that the ethnicity of the patients plays a major role in the changes of miRNA expression and must be taken into consideration in future studies.

\section{IncRNA in Depression}

\subsection{IncRNA Description and Functions}

Long noncoding RNAs belong to the least known group of noncoding RNA molecules, probably as a result of their low expression level and poor sequence conservation [186-188]. However, they have gained the attention of scientists due to their capability of gene expression regulation. lncRNAs, above 200-nucleotide-long RNA particles, do not encode any proteins. They are multitask molecules participating in the regulation of DNA methylation, histone modifications and chromatin remodeling, as well as controlling gene expression via transcriptional and post-transcriptional mechanisms [189,190]. lncRNAs are known to interact with mRNAs, serve as miRNA sponges, decoy or scaffold molecules $[187,191]$. Therefore, lncRNAs may be present in both nucleus and cytoplasm [192].

There are several ways of classifying lncRNAs. Taking into account their origin, one could distinguish intergenic and intronic lncRNAs. Intergenic lncRNAs are transcribed from intergenic-noncoding regions between genes, while intronic ones are obtained from introns of protein-coding genes [193]. To date, intergenic lncRNAs also known as lincRNAs, are some of the best described representatives of lncRNAs [194]. Moreover, lncRNAs can be transcribed in either sense or antisense orientation [195]. Considering the regulatory function of lncRNAs, they may act in two ways: cis-interacting with neighboring protein-coding genes, and trans-influencing expression of distant genes [196]. Finally, the length also makes them simply categorized into small ( $<950 \mathrm{nt}$, the most abundant group), medium (950-4800 nt) and large (>4800 nt) lncRNAs [194].

\subsection{IncRNA in the Nervous System}

Interestingly, a significant part of known lncRNAs has been found to be expressed in brain tissue $[197,198]$. There are many described lncRNAs (Table 6) that are involved in different stages of brain development and its activity. Some important examples are RMST, which is engaged in neurogenesis, or MALAT1, which participates in synaptogenesis $[195,199,200]$. Therefore, studies have started to investigate the roles of lncRNAs in the pathogenesis of mental disorders, including depression [189]. 
Table 6. Examples of lncRNA roles in neural development and pathogenesis.

\begin{tabular}{|c|c|c|c|c|}
\hline $\operatorname{lncRNA}$ & Mechanism of Action & Function & Pathological State & References \\
\hline BC200 & $\begin{array}{l}\text { Inhibition of translation initiation } \\
\text { in dendrites }\end{array}$ & $\begin{array}{l}\text { Support of long-term synaptic } \\
\text { plasticity }\end{array}$ & $\begin{array}{l}\text { Alzheimer's disease } \\
\text { and Parkinson's } \\
\text { disease }\end{array}$ & {$[188,195]$} \\
\hline UCHL1-AS & $\begin{array}{c}\text { Enhancement of translation of } \\
\text { UCHL1 mRNA }\end{array}$ & $\begin{array}{c}\text { Involved in proper neurons } \\
\text { development }\end{array}$ & Parkinson's disease & [188] \\
\hline HTT-AS & $\begin{array}{c}\text { Negative regulation of HTT } \\
\text { expression }\end{array}$ & $\begin{array}{l}\text { Maintenance of proper nervous } \\
\text { system functioning }\end{array}$ & Huntington's disease & [188] \\
\hline Camkk1 & $\begin{array}{c}\text { Regulation of } \\
\mathrm{Ca} 2+/ \text { calmodulin-dependent } \\
\text { protein kinase II }\end{array}$ & Long-term memory maintenance & Lack of evidence & {$[195,199]$} \\
\hline $\begin{array}{l}\text { Evx1as and } \\
\text { Hox } 5 \mathrm{~b} / 6 \text { as are }\end{array}$ & $\begin{array}{l}\text { Interaction with } \mathrm{H} 3 \mathrm{~K} 4 \text { histone and } \\
\text { histone methyltransferase }\end{array}$ & $\begin{array}{l}\text { Maintenance of proper nervous } \\
\text { system functioning }\end{array}$ & Lack of evidence & [199] \\
\hline Tuna & $\begin{array}{c}\text { Regulation of gene expression in } \\
\text { neural cells }\end{array}$ & $\begin{array}{l}\text { Maintenance of proper nervous } \\
\text { system functioning }\end{array}$ & Lack of evidence & [199] \\
\hline Sox2OT & Overlapping with Sox 2 gene & $\begin{array}{l}\text { Involved in development of } \\
\text { neural stem and progenitor cells }\end{array}$ & $\begin{array}{l}\text { Alzhaimer's disease } \\
\text { and Parkinson's } \\
\text { disease }\end{array}$ & {$[195,199]$} \\
\hline RMST & $\begin{array}{c}\text { Regulation of neural cells } \\
\text { differentiation }\end{array}$ & Involved in neurogenesis & Lack of evidence & [199] \\
\hline $\mathrm{Nkx2.2AS}$ & Regulation of Nkx2.2 mRNA level & $\begin{array}{l}\text { Maintenance of } \\
\text { oligodendrocytes differentiation }\end{array}$ & Lack of evidence & {$[195,199]$} \\
\hline HAR1F & $\begin{array}{l}\text { Regulation of migration of neural } \\
\text { cells and forebrain organization }\end{array}$ & $\begin{array}{l}\text { Development of human } \\
\text { embryonic neocortex }\end{array}$ & Huntington's disease & {$[195,199]$} \\
\hline Malat1 & $\begin{array}{l}\text { Regulation of SR-family splicing } \\
\text { factors }\end{array}$ & Involved in synaptogenesis & Lack of evidence & [199] \\
\hline BDNF-AS & Reducing level of BDNF factor & $\begin{array}{c}\text { Involved in neurons } \\
\text { development }\end{array}$ & Schizophrenia & {$[195,199]$} \\
\hline Gomafu & Binding to splicing factors & Involved in neural development & Schizophrenia & {$[195,199]$} \\
\hline
\end{tabular}

Although the research is in its infancy, several lncRNAs correlated with MDD have been already reported. The study of Hosseini et al. demonstrated that lncRNAs NRON (repressor of nuclear factor of activated T cells NFAT) and BACE1-AS (an antisense transcript of B-secretase 1) modulate expression of relevant protein-coding genes involved in proper nervous system function. Furthermore, downregulation or knockdown of BDNF-AS lncRNA upregulated BDNF expression, leading to elevation of GDNF and EPH receptor B2 and activation of neuron development [133]. BDNF-AS was also found in animals showing the ability to halt BDNF transcription [201].

Another research group [202] performed microarray-based genome-wide studies and identified six lncRNAs: TCONS_00019174, ENST00000566208, NONHSAG045500, ENST00000517573, NONHSAT034045, and NONHSAT142707, which exhibited significant expression changes in patients with depression as compared to patients after remission. The group also showed that the lncRNAs have significant correlation with suicide risk [202]. The study by Liu et al. [201] reported that overexpression of NONHSAG045500 inhibits transcription of serotonin transporter SERT in vitro.

The animal model with depression-like symptoms triggered by the procedure of learned helplessness proved the previous results, that lncRNAs may have an impact on regulatory mechanisms implicated in depression [200] This study suggested that disturbance of lncRNAs in the brain may be involved in stress-induced pathologies such as synaptic dysfunction. Other studies with mice revealed that depression-related behavioral tests, such as elevated plus maze, forced-swim test, and tail suspension test themselves could cause the changes of mRNA and lncRNA expression [203]. However, the general translation of animal studies might cause some difficulties due to low conservation of lncRNAs between humans and other species [188,197]. 


\subsection{IncRNAs as Depression Biomarkers}

Similar to other non-coding RNAs, miRNAs and lncRNAs are expected to become MDD biomarkers [189,204]. Despite the evident regulatory role of lncRNAs in expression of essential genes for neural system development, a number of studies show that lncRNA expression may vary in several neuropsychiatric disorders, such as autism spectrum disorders, schizophrenia and depression [199]. To the best of our knowledge, there is only one study, performed by Liu et al., showing 2007 diversely expressed lncRNAs in the peripheral blood of patients with depression as compared to the control group. Also, attempts have been made to analyze co-expression of lncRNAs and mRNAs, giving a broader view on epigenetic regulation in depression. From those 2007 lncRNAs: chr10:874695-874794, chr10:75873456-75873642, and chr3:47048304-47048512 were found to interact with mRNAs differentially expressed in depressed patients [205]. Thus, IncRNAs may be involved in the pathogenesis of depression also via mRNA regulation [189]. However, only a few studies have examined circulating lncRNAs in the blood of patients with depression [190,202,205-207]

Currently, there are several ongoing pre-clinical trials evaluating the potential of using lncRNAs as disease biomarkers [188]. For instance, GAS5 lncRNA may serve as a possible biomarker for type 2 diabetes (T2DM) and coronary artery disease (CAD) [208]. Moreover, NBAT-1 and SNGH1 may become diagnostic markers of tumorigenesis in various cancer types $[209,210]$. To date, no clinical approaches in depression treatment have been published.

\subsection{Future Research}

To date, the knowledge regarding lncRNAs in depression and its therapy is rather scarce. As some lncRNAs have been indicated as especially interesting in other psychiatric disorders, e.g., Gomafu lncRNA related to schizophrenia or AS-Uchl1 in Parkinson's disease, it would be interesting to evaluate their contribution to depression pathogenesis and treatment efficacy in numerous novel studies [198,199]. As mentioned earlier, lncRNA NONHSAG045500 shows an interesting correlation with serotonin transporter, making it a promising target for future antidepressant therapy. Even though there are only several reports about lncRNAs' role in depression, the lncRNA abundance in the brain leaves a wide margin for prospective research.

\section{Conclusions}

Collected data strongly suggest that epigenetic modifications are associated with etiopathogenesis of depression, neuroplasticity, antidepressant treatment and, finally, could be regarded as potential depression biomarkers. Interestingly, epigenetic marks are ones introduced during harmful early-life events, reflecting an increased vulnerability to depression during one's lifetime. Presented data also suggest that, from the clinical point of view, HDACis could possibly serve as new antidepressant agents even in the near future. Moreover, while the involvement of DNA methylation, histone modifications and miRNA expression changes have been substantially investigated in the pathogenesis and therapy of depression, the research oriented toward lncRNAs is still in its infancy. Therefore, studying interactions among lncRNAs, miRNAs and numerous target mRNAs could be an interesting direction of future research, not only in the context of depression, but also other neuropsychiatric diseases. Similarly, there is still a lack of data providing a global view on the crosstalk among the above epigenetic marks in depression. However, conclusions from currently available studies are often inconsistent, being possibly associated with methodological issues or ones emerging from ethnic differences. Having obtained promising results so far, we believe there is still a great need for further research addressing these important issues and showing a broader picture of the epigenetic landscape in depression and its therapy. 
Author Contributions: Conceptualization, P.C., K.B., S.Z., T.S.; Methodology, P.C., K.B., S.Z.; WritingOriginal Draft Preparation, P.C., K.B., S.Z., J.S., G.B.; Writing-Review and Editing, P.C., T.S.; Visualization, S.Z., K.B., G.B.; Supervision, T.S.; Project Administration, P.C.; Funding Acquisition, P.C., T.S. All authors have read and agreed to the published version of the manuscript.

Funding: This research received no external funding.

Institutional Review Board Statement: Not applicable.

Informed Consent Statement: Not applicable.

Conflicts of Interest: The authors declare no conflict of interest.

\section{References}

1. Kennis, M.; Gerritsen, L.; Van Dalen, M.; Williams, A.; Cuijpers, P.; Bockting, C. Prospective biomarkers of major depressive disorder: A systematic review and meta-analysis. Mol. Psychiatry 2020, 25, 321-338. [CrossRef]

2. Pitsillou, E.; Bresnehan, S.M.; Kagarakis, E.A.; Wijoyo, S.J.; Liang, J.; Hung, A.; Karagiannis, T.C. The cellular and molecular basis of major depressive disorder: Towards a unified model for understanding clinical depression. Mol. Biol. Rep. 2020, 47, 753-770. [CrossRef] [PubMed]

3. Wray, N.R.; Ripke, S.; Mattheisen, M.; Trzaskowski, M.; Byrne, E.M.; Abdellaoui, A.; Adams, M.J.; Agerbo, E.; Air, T.M.; Andlauer, T.M.F.; et al. Genome-wide association analyses identify 44 risk variants and refine the genetic architecture of major depression. Nat. Genet. 2018, 50, 668-681. [CrossRef]

4. Sullivan, P.F.; Neale, M.C.; Kendler, K.S. Genetic Epidemiology of Major Depression: Review and Meta-Analysis. Am. J. Psychiatry 2000, 157, 1552-1562. [CrossRef] [PubMed]

5. Sun, H.; Kennedy, P.J.; Nestler, E.J. Epigenetics of the Depressed Brain: Role of Histone Acetylation and Methylation. Neuropsychopharmacology 2013, 38, 124-137. [CrossRef]

6. Li, M.; D'Arcy, C.; Li, X.; Zhang, T.; Joober, R.; Meng, X. What do DNA methylation studies tell us about depression? A systematic review. Transl. Psychiatry 2019, 9, 1-14. [CrossRef]

7. Uchida, S.; Yamagata, H.; Seki, T.; Watanabe, Y. Epigenetic mechanisms of major depression: Targeting neuronal plasticity. Psychiatry Clin. Neurosci. 2018, 72, 212-227. [CrossRef] [PubMed]

8. Chen, D.; Meng, L.; Pei, F.; Zheng, Y.; Leng, J. A review of DNA methylation in depression. J. Clin. Neurosci. 2017, 43, 39-46. [CrossRef]

9. Kriaucionis, S.; Heintz, N. The Nuclear DNA Base 5-Hydroxymethylcytosine Is Present in Purkinje Neurons and the Brain. Science 2009, 324, 929-930. [CrossRef]

10. Catalanotto, C.; Cogoni, C.; Zardo, G. MicroRNA in Control of Gene Expression: An Overview of Nuclear Functions. Int. J. Mol. Sci. 2016, 17, 1712. [CrossRef]

11. Morlando, M.; Fatica, A. Alteration of Epigenetic Regulation by Long Noncoding RNAs in Cancer. Int. J. Mol. Sci. 2018, 19, 570. [CrossRef]

12. Hulshoff, M.S.; Xu, X.; Krenning, G.; Zeisberg, E.M. Epigenetic Regulation of Endothelial-to-Mesenchymal Transition in Chronic Heart Disease. Arter. Thromb. Vasc. Biol. 2018, 38, 1986-1996. [CrossRef] [PubMed]

13. Ma, N.; Tie, C.; Yu, B.; Zhang, W.; Wan, J. Identifying lncRNA-miRNA-mRNA networks to investigate Alzheimer's disease pathogenesis and therapy strategy. Aging 2020, 12, 2897-2920. [CrossRef] [PubMed]

14. Nafee, T.M.; Farrell, W.E.; Carroll, W.D.; Fryer, A.A.; Ismail, K.M.K. Epigenetic control of fetal gene expression. Int. J. Obstet. Gynaecol. 2007, 115, 158-168. [CrossRef] [PubMed]

15. Kondo, Y. Epigenetic Cross-Talk between DNA Methylation and Histone Modifications in Human Cancers. Yonsei Med. J. 2009, 50, 455-463. [CrossRef] [PubMed]

16. Vialou, V.; Feng, J.; Robison, A.J.; Nestler, E.J. Epigenetic Mechanisms of Depression and Antidepressant Action. Annu. Rev. Pharmacol. Toxicol. 2013, 53, 59-87. [CrossRef]

17. Murgatroyd, C.; Patchev, A.V.; Wu, Y.; Micale, V.; Bockmühl, Y.; Fischer, D.; Holsboer, F.; Wotjak, C.T.; Almeida, O.F.X.; Spengler, D. Dynamic DNA methylation programs persistent adverse effects of early-life stress. Nat. Neurosci. 2009, 12, 1559-1566. [CrossRef]

18. Lin, E.; Tsai, S.-J. Epigenetics and Depression: An Update. Psychiatry Investig. 2019, 16, 654-661. [CrossRef]

19. Volkow, N.D.; Koob, G.; Baler, R. Biomarkers in Substance Use Disorders. ACS Chem. Neurosci. 2015, 6, 522-525. [CrossRef] [PubMed]

20. Saavedra, K.; Molina-Márquez, A.M.; Saavedra, N.; Zambrano, T.; Salazar, L.A. Epigenetic Modifications of Major Depressive Disorder. Int. J. Mol. Sci. 2016, 17, 1279. [CrossRef]

21. Córdova-Palomera, A.; Fatjó-Vilas, M.; Gastó, C.; Navarro, V.; Krebs, M.-O.; Fañanás, L. Genome-wide methylation study on depression: Differential methylation and variable methylation in monozygotic twins. Transl. Psychiatry 2015, 5, e557. [CrossRef] [PubMed]

22. Januar, V.; Ancelin, M.-L.; Ritchie, K.; Saffery, R.; Ryan, J. BDNF promoter methylation and genetic variation in late-life depression. Transl. Psychiatry 2015, 5, e619. [CrossRef] [PubMed] 
23. Kang, H.-J.; Kim, J.-M.; Kim, S.-Y.; Kim, S.-W.; Shin, I.-S.; Kim, H.-R.; Park, M.-H.; Shin, M.-G.; Yoon, J.-H.; Yoon, J.-S. A Longitudinal Study of BDNF Promoter Methylation and Depression in Breast Cancer. Psychiatry Investig. 2015, 12, 523-531. [CrossRef]

24. D'Addario, C.; Dell'Osso, B.; Galimberti, D.; Palazzo, M.C.; Benatti, B.; Di Francesco, A.; Scarpini, E.; Altamura, A.C.; Maccarrone, M. Epigenetic modulation of BDNF gene in patients with major depressive disorder. Biol. Psychiatry 2013, 73, e6-e7. [CrossRef]

25. Tadić, A.; Müller-Engling, L.; Schlicht, K.F.; Kotsiari, A.; Dreimüller, N.; Kleimann, A.; Bleich, S.; Lieb, K.; Frieling, H. Methylation of the promoter of brain-derived neurotrophic factor exon IV and antidepressant response in major depression. Mol. Psychiatry 2014, 19, 281-283. [CrossRef]

26. Braithwaite, E.C.; Kundakovic, M.; Ramchandani, P.G.; Murphy, S.E.; Champagne, F.A. Maternal prenatal depressive symptoms predict infant NR3C1 1F and BDNF IV DNA methylation. Epigenetics 2015, 10, 408-417. [CrossRef] [PubMed]

27. Devlin, A.M.; Brain, U.; Austin, J.; Oberlander, T.F. Prenatal exposure to maternal depressed mood and the MTHFR C677T variant affect SLC6A4 methylation in infants at birth. PLoS ONE 2010, 5, e12201. [CrossRef]

28. Booij, L.; Szyf, M.; Carballedo, A.; Frey, E.-M.; Morris, D.; Dymov, S.; Vaisheva, F.; Ly, V.; Fahey, C.; Meaney, J.; et al. DNA methylation of the serotonin transporter gene in peripheral cells and stress-related changes in hippocampal volume: A study in depressed patients and healthy controls. PLoS ONE 2015, 10, e0119061. [CrossRef]

29. Kang, H.-J.; Kim, J.-M.; Stewart, R.; Kim, S.-Y.; Bae, K.-Y.; Kim, S.-W.; Shin, I.-S.; Shin, M.-G.; Yoon, J.-S. Association of SLC6A4 methylation with early adversity, characteristics and outcomes in depression. Prog. Neuro-Psychopharmacol. Biol. Psychiatry 2013, 44, 23-28. [CrossRef]

30. Zhao, J.; Goldberg, J.; Bremner, J.D.; Vaccarino, V. Association between promoter methylation of serotonin transporter gene and depressive symptoms: A monozygotic twin study. Psychosom. Med. 2013, 75, 523-529. [CrossRef]

31. Domschke, K.; Tidow, N.; Schwarte, K.; Deckert, J.; Lesch, K.-P.; Arolt, V.; Zwanzger, P.; Baune, B.T. Serotonin transporter gene hypomethylation predicts impaired antidepressant treatment response. Int. J. Neuropsychopharmacol. 2014, 17, 1167-1176. [CrossRef] [PubMed]

32. Okada, S.; Morinobu, S.; Fuchikami, M.; Segawa, M.; Yokomaku, K.; Kataoka, T.; Okamoto, Y.; Yamawaki, S.; Inoue, T.; Kusumi, I.; et al. The potential of SLC6A4 gene methylation analysis for the diagnosis and treatment of major depression. J. Psychiatr. Res. 2014, 53, 47-53. [CrossRef]

33. Schiele, M.A.; Zwanzger, P.; Schwarte, K.; Arolt, V.; Baune, B.T.; Domschke, K. Serotonin transporter gene promoter hypomethylation as a predictor of antidepressant treatment response in major depression-A replication study. Int. J. Neuropsychopharmacol. 2020. [CrossRef] [PubMed]

34. Perroud, N.A.; Paolonigiacobino, A.; Prada, P.B.; Olié, E.; Salzmann, A.; Nicastro, R.; Guillaume, S.; Mouthon-Mermoud, D.; Stouder, C.; Dieben, K.; et al. Increased methylation of glucocorticoid receptor gene (NR3C1) in adults with a history of childhood maltreatment: A link with the severity and type of trauma. Transl. Psychiatry 2011, 1, e59. [CrossRef]

35. Cardenas, A.; Faleschini, S.; Hidalgo, A.C.; Rifas-Shiman, S.L.; Baccarelli, A.A.; DeMeo, D.L.; Litonjua, A.A.; Neumann, A.; Felix, J.F.; Jaddoe, V.W.V.; et al. Prenatal maternal antidepressants, anxiety, and depression and offspring DNA methylation: Epigenome-wide associations at birth and persistence into early childhood. Clin. Epigenet. 2019, 11, 56. [CrossRef]

36. Takeuchi, N.; Nonen, S.; Kato, M.; Wakeno, M.; Takekita, Y.; Kinoshita, T.; Kugawa, F. Therapeutic Response to Paroxetine in Major Depressive Disorder Predicted by DNA Methylation. Neuropsychobiology 2018, 75, 81-88. [CrossRef] [PubMed]

37. Powell, T.R.; Smith, R.G.; Hackinger, S.; Schalkwyk, L.C.; Uher, R.; McGuffin, P.; Mill, J.; E Tansey, K. DNA methylation in interleukin-11 predicts clinical response to antidepressants in GENDEP. Transl. Psychiatry 2013, 3, e300. [CrossRef]

38. Shen, T.; Li, X.; Chen, L.; Chen, Z.; Tan, T.; Hua, T.; Chen, B.; Yuan, Y.; Zhang, Z.; Kuney, L.; et al. The relationship of tryptophan hydroxylase-2 methylation to early-life stress and its impact on short-term antidepressant treatment response. J. Affect. Disord. 2020, 276, 850-858. [CrossRef] [PubMed]

39. Sabunciyan, S.; Aryee, M.J.; Irizarry, R.A.; Rongione, M.; Webster, M.J.; Kaufman, W.E.; Murakami, P.; Lessard, A.; Yolken, R.H.; Feinberg, A.P.; et al. Genome-wide DNA methylation scan in major depressive disorder. PLoS ONE 2012, 7, e34451. [CrossRef]

40. Fuchikami, M.; Morinobu, S.; Segawa, M.; Okamoto, Y.; Yamawaki, S.; Ozaki, N.; Inoue, T.; Kusumi, I.; Koyama, T.; Tsuchiyama, K.; et al. DNA methylation profiles of the brain-derived neurotrophic factor (BDNF) gene as a potent diagnostic biomarker in major depression. PLoS ONE 2011, 6, e23881. [CrossRef]

41. Martinowich, K.; Hattori, D.; Wu, H.; Fouse, S.; He, F.; Hu, Y.; Fan, G.; Sun, Y.E. DNA methylation-related chromatin remodeling in activity-dependent BDNF gene regulation. Science 2003, 302, 890-893. [CrossRef] [PubMed]

42. Kang, H.-J.; Kim, J.-M.; Lee, J.-Y.; Kim, S.-Y.; Bae, K.-Y.; Kim, S.-W.; Shin, I.-S.; Kim, H.-R.; Shin, M.-G.; Yoon, J.-S. BDNF promoter methylation and suicidal behavior in depressive patients. J. Affect. Disord. 2013, 151, 679-685. [CrossRef]

43. Roth, T.L.; Lubin, F.D.; Funk, A.J.; Sweatt, J.D. Lasting epigenetic influence of early-life adversity on the BDNF gene. Biol. Psychiatry 2009, 65, 760-769. [CrossRef]

44. Jin, H.-J.; Pei, L.; Li, Y.-N.; Zheng, H.; Yang, S.; Wan, Y.; Mao, L.; Xia, Y.-P.; He, Q.-W.; Li, M.; et al. Alleviative effects of fluoxetine on depressive-like behaviors by epigenetic regulation of BDNF gene transcription in mouse model of post-stroke depression. Sci. Rep. 2017, 7, 1-15. [CrossRef]

45. Wigner, P.; Synowiec, E.; Jóźwiak, P.; Czarny, P.; Bijak, M.; Białek, K.; Szemraj, J.; Gruca, P.; Papp, M.; Śliwiński, T. The Effect of Chronic Mild Stress and Venlafaxine on the Expression and Methylation Levels of Genes Involved in the Tryptophan Catabolites Pathway in the Blood and Brain Structures of Rats. J. Mol. Neurosci. 2020, 70, 1425-1436. [CrossRef] 
46. Wigner, P.; Synowiec, E.; Jóźwiak, P.; Czarny, P.; Bijak, M.; Barszczewska, G.; Białek, K.; Szemraj, J.; Gruca, P.; Papp, M.; et al. The Changes of Expression and Methylation of Genes Involved in Oxidative Stress in Course of Chronic Mild Stress and Antidepressant Therapy with Agomelatine. Genes 2020, 11, 644. [CrossRef]

47. Booij, L.; Szyf, M.; Carballedo, A.; Frey, E.-M.; Morris, D.; Ly, V.; Fahey, C.; Meaney, J.; Gill, M.; Frodl, T. The role of SLC6A4 DNA methylation in stress-related changes in hippocampal volume: A study in depressed patients and healthy controls. In Proceedings of the 29th CINP World Congress of Neuropsychopharmacology, Vancouver, BC, Canada, 22-26 June 2014.

48. Chiarella, J.; Schumann, L.; Pomares, F.B.; Frodl, T.; Tozzi, L.; Nemoda, Z.; Yu, P.; Szyf, M.; Khalid-Khan, S.; Booij, L. DNA methylation differences in stress-related genes, functional connectivity and gray matter volume in depressed and healthy adolescents. J. Affect. Disord. 2020, 271, 160-168. [CrossRef] [PubMed]

49. Weaver, I.C.G.; Cervoni, N.; Champagne, F.A.; D'Alessio, A.C.; Sharma, S.; Seckl, J.R.; Dymov, S.; Szyf, M.; Meaney, M.J. Epigenetic programming by maternal behavior. Nat. Neurosci. 2004, 7, 847-854. [CrossRef]

50. Fuchikami, M.; Morinobu, S.; Kurata, A.; Yamamoto, S.; Yamawaki, S. Single immobilization stress differentially alters the expression profile of transcripts of the brain-derived neurotrophic factor (BDNF) gene and histone acetylation at its promoters in the rat hippocampus. Int. J. Neuropsychopharmacol. 2009, 12, 73-82. [CrossRef]

51. Gassen, N.C.; Fries, G.R.; Zannas, A.S.; Hartmann, J.; Zschocke, J.; Hafner, K.; Carrillo-Roa, T.; Steinbacher, J.; Preißinger, S.N.; Hoeijmakers, L.; et al. Chaperoning epigenetics: FKBP51 decreases the activity of DNMT1 and mediates epigenetic effects of the antidepressant paroxetine. Sci. Signal. 2015, 8, ra119. [CrossRef] [PubMed]

52. Zimmermann, N.; Zschocke, J.; Perisic, T.; Yu, S.; Holsboer, F.; Rein, T. Antidepressants inhibit DNA methyltransferase 1 through reducing G9a levels. Biochem. J. 2012, 448, 93-102. [CrossRef]

53. Le François, B.; Soo, J.; Millar, A.M.; Daigle, M.; Le Guisquet, A.-M.; Leman, S.; Minier, F.; Belzung, C.; Albert, P.R. Chronic mild stress and antidepressant treatment alter 5-HT1A receptor expression by modifying DNA methylation of a conserved Sp4 site. Neurobiol. Dis. 2015, 82, 332-341. [CrossRef] [PubMed]

54. Elliott, E.; Ezra-Nevo, G.; Regev, L.; Neufeld-Cohen, A.; Chen, A. Resilience to social stress coincides with functional DNA methylation of the Crf gene in adult mice. Nat. Neurosci. 2010, 13, 1351-1353. [CrossRef]

55. Sales, A.J.; Joca, S.R.L. Antidepressant administration modulates stress-induced DNA methylation and DNA methyltransferase expression in rat prefrontal cortex and hippocampus. Behav. Brain Res. 2018, 343, 8-15. [CrossRef] [PubMed]

56. Sales, A.J.; Biojone, C.; Terceti, M.S.; Guimarães, F.S.; Gomes, M.V.M.; Joca, S.R.L. Antidepressant-like effect induced by systemic and intra-hippocampal administration of DNA methylation inhibitors. Br. J. Pharmacol. 2011, 164, 1711-1721. [CrossRef]

57. Sales, A.J.; Joca, S.R.L. Effects of DNA methylation inhibitors and conventional antidepressants on mice behaviour and brain DNA methylation levels. Acta Neuropsychiatr. 2015, 28, 11-22. [CrossRef]

58. Nestler, E.J.; Peña, C.J.; Kundakovic, M.; Mitchell, A.; Akbarian, S. Epigenetic Basis of Mental Illness. Neuroscientist 2016, 22, 447-463. [CrossRef]

59. Belzeaux, R.; Lin, R.; Ju, C.; Chay, M.-A.; Fiori, L.M.; Lutz, P.-E.; Turecki, G. Transcriptomic and epigenomic biomarkers of antidepressant response. J. Affect. Disord. 2018, 233, 36-44. [CrossRef] [PubMed]

60. Liu, Y.; Li, M.; Fan, M.; Song, Y.; Yu, H.; Zhi, X.; Xiao, K.; Lai, S.; Zhang, J.; Jin, X.; et al. Chromodomain Y-like Protein-Mediated Histone Crotonylation Regulates Stress-Induced Depressive Behaviors. Biol. Psychiatry 2019, 85, 635-649. [CrossRef] [PubMed]

61. Chan, J.C.; Maze, I. Histone Crotonylation Makes Its Mark in Depression Research. Biol. Psychiatry 2019, 85, 616-618. [CrossRef] [PubMed]

62. Renthal, W.; Maze, I.; Krishnan, V.; Covington, H.E., 3rd; Xiao, G.; Kumar, A.; Russo, S.J.; Graham, A.; Tsankova, N.; Kippin, T.E. Histone deacetylase 5 epigenetically controls behavioral adaptations to chronic emotional stimuli. Neuron 2007, 56, 517-529. [CrossRef] [PubMed]

63. Zheng, Y.; Fan, W.; Zhang, X.; Dong, E. Gestational stress induces depressive-like and anxiety-like phenotypes through epigenetic regulation of BDNF expression in offspring hippocampus. Epigenetics 2016, 11, 150-162. [CrossRef]

64. Covington, H.E., 3rd; Maze, I.; LaPlant, Q.C.; Vialou, V.F.; Ohnishi, Y.N.; Berton, O.; Fass, D.M.; Renthal, W.; Rush, A.J., 3rd; $\mathrm{Wu}$, E.Y. Antidepressant actions of histone deacetylase inhibitors. J. Neurosci. 2009, 29, 11451-11460. [CrossRef]

65. Covington, H.E., 3rd; Maze, I.; Sun, H.; Bomze, H.M.; DeMaio, K.D.; Wu, E.Y.; Dietz, D.M.; Lobo, M.K.; Ghose, S.; Mouzon, E. A role for repressive histone methylation in cocaine-induced vulnerability to stress. Neuron 2011, 71, 656-670. [CrossRef] [PubMed]

66. Romero, S.M.; Montesinos, J.; Pascual, M.; Aguilar, M.; Roger-Sanchez, C.; Guerri, C.; Miñarro, J.; Rodríguez-Arias, M. Upregulation of histone acetylation induced by social defeat mediates the conditioned rewarding effects of cocaine. Prog. Neuropsychopharmacol. Biol. Psychiatry 2016, 70, 39-48. [CrossRef]

67. Han, A.; Sung, Y.-B.; Chung, S.-Y.; Kwon, M.-S. Possible additional antidepressant-like mechanism of sodium butyrate: Targeting the hippocampus. Neuropharmacology 2014, 81, 292-302. [CrossRef]

68. Maury, E.; Hashizume, R. Epigenetic modification in chromatin machinery and its deregulation in pediatric brain tumors: Insight into epigenetic therapies. Epigenetic 2017, 12, 353-369. [CrossRef] [PubMed]

69. Tsankova, N.M.; Berton, O.; Renthal, W.; Kumar, A.; Neve, R.L.; Nestler, E.J. Sustained hippocampal chromatin regulation in a mouse model of depression and antidepressant action. Nat. Neurosci. 2006, 9, 519-525. [CrossRef] [PubMed] 
70. Xu, H.; Wang, J.; Zhang, K.; Zhao, M.; Ellenbroek, B.; Shao, F.; Wang, W. Effects of adolescent social stress and antidepressant treatment on cognitive inflexibility and Bdnf epigenetic modifications in the mPFC of adult mice. Psychoneuroendocrinology 2018, 88, 92-101. [CrossRef]

71. Chen, L.; Miao, Z.; Xu, X. $\beta$-hydroxybutyrate alleviates depressive behaviors in mice possibly by increasing the histone3-lysine9$\beta$-hydroxybutyrylation. Biochem. Biophys. Res. Commun. 2017, 490, 117-122. [CrossRef]

72. Francis, D.D.; Szegda, K.; Campbell, G.; Martin, W.D.; Insel, T.R. Epigenetic sources of behavioral differences in mice. Nat. Neurosci. 2003, 6, 445-446. [CrossRef] [PubMed]

73. Tarantino, L.M.; Sullivan, P.F.; Meltzer-Brody, S. Using animal models to disentangle the role of genetic, epigenetic, and environmental influences on behavioral outcomes associated with maternal anxiety and depression. Front. Psychiatry 2011, 2, 44. [CrossRef]

74. Uchida, S.; Hara, K.; Kobayashi, A.; Otsuki, K.; Yamagata, H.; Hobara, T.; Suzuki, T.; Miyata, N.; Watanabe, Y. Epigenetic status of Gdnf in the ventral striatum determines susceptibility and adaptation to daily stressful events. Neuron 2011, 69, 359-372. [CrossRef]

75. Köhler, J.C.; Gröger, N.; Lesse, A.; Ciurana, S.G.; Rether, K.; Fegert, J.; Bock, J.; Braun, K. Early-Life Adversity Induces Epigenetically Regulated Changes in Hippocampal Dopaminergic Molecular Pathways. Mol. Neurobiol. 2019, 56, $3616-3625$. [CrossRef] [PubMed]

76. Seo, M.K.; Kim, S.-G.; Seog, D.-H.; Bahk, W.-M.; Kim, S.-H.; Park, S.W.; Lee, J.G. Effects of Early Life Stress on Epigenetic Changes of the Glucocorticoid Receptor 1(7) Promoter during Adulthood. Int. J. Mol. Sci. 2020, 21, 6331. [CrossRef] [PubMed]

77. Kenworthy, C.; Sengupta, A.; Luz, S.; Hoeve, E.V.; Meda, K.; Bhatnagar, S.; Abel, T. Social defeat induces changes in histone acetylation and expression of histone modifying enzymes in the ventral hippocampus, prefrontal cortex, and dorsal raphe nucleus. Neuroscience 2014, 264, 88-98. [CrossRef] [PubMed]

78. Liu, D.; Qiu, H.-M.; Fei, H.-Z.; Hu, X.-Y.; Xia, H.-J.; Wang, L.-J.; Qin, L.-J.; Jiang, X.-H.; Zhou, Q.-X. Histone acetylation and expression of mono-aminergic transmitters synthetases involved in CUS-induced depressive rats. Exp. Biol. Med. 2014, 239, 330-336. [CrossRef]

79. Li, H.-Y.; Jiang, Q.-S.; Fu, X.-Y.; Jiang, X.-H.; Zhou, Q.-X.; Qiu, H.-M. Abnormal modification of histone acetylation involved in depression-like behaviors of rats induced by chronically unpredicted stress. Neuroreport 2017, 28, 1054-1060. [CrossRef] [PubMed]

80. Wan, Q.; Gao, K.; Rong, H.; Wu, M.; Wang, H.; Wang, X.; Wang, G.; Liu, Z. Histone modifications of the Crhr1 gene in a rat model of depression following chronic stress. Behav. Brain Res. 2014, 271, 1-6. [CrossRef]

81. Hunter, R.G.; McCarthy, K.J.; Milne, T.A.; Pfaff, D.W.; McEwen, B.S. Regulation of hippocampal H3 histone methylation by acute and chronic stress. Proc. Natl. Acad. Sci. USA 2009, 106, 20912-20917. [CrossRef]

82. Taufique, S.K.T.; Prabhat, A.; Kumar, V. Illuminated night alters hippocampal gene expressions and induces depressive-like responses in diurnal corvids. Eur. J. Neurosci. 2018, 48, 3005-3018. [CrossRef]

83. Hobara, T.; Uchida, S.; Otsuki, K.; Matsubara, T.; Funato, H.; Matsuo, K.; Suetsugi, M.; Watanabe, Y. Altered gene expression of histone deacetylases in mood disorder patients. J. Psychiatr. Res. 2010, 44, 263-270. [CrossRef] [PubMed]

84. Iga, J.-I.; Ueno, S.-I.; Yamauchi, K.; Numata, S.; Kinouchi, S.; Tayoshi-Shibuya, S.; Song, H.; Ohmori, T. Altered HDAC5 and CREB mRNA expressions in the peripheral leukocytes of major depression. Prog. Neuropsychopharmacol. Biol. Psychiatry 2007, 31, 628-632. [CrossRef] [PubMed]

85. Nagy, C.; Torres-Platas, S.G.; Mechawar, N.; Turecki, G. Repression of Astrocytic Connexins in Cortical and Subcortical Brain Regions and Prefrontal Enrichment of H3K9me3 in Depression and Suicide. Int. J. Neuropsychopharmacol. 2017, $20,50-57$. [CrossRef]

86. Cruceanu, C.; Alda, M.; Nagy, C.; Freemantle, E.; Rouleau, G.A.; Turecki, G. H3K4 tri-methylation in synapsin genes leads to different expression patterns in bipolar disorder and major depression. Int. J. Neuropsychopharmacol. 2013, 16, 289-299. [CrossRef] [PubMed]

87. Fass, D.M.; Reis, S.A.; Ghosh, B.; Hennig, K.M.; Joseph, N.F.; Zhao, W.-N.; Nieland, T.J.; Guan, J.-S.; Kuhnle, C.E.G.; Tang, W.; et al. Crebinostat: A novel cognitive enhancer that inhibits histone deacetylase activity and modulates chromatin-mediated neuroplasticity. Neuropharmacology 2013, 64, 81-96. [CrossRef] [PubMed]

88. Ghosh, B.; Zhao, W.-N.; Reis, S.A.; Patnaik, D.; Fass, D.M.; Tsai, L.-H.; Mazitschek, R.; Haggarty, S.J. Dissecting structure-activityrelationships of crebinostat: Brain penetrant HDAC inhibitors for neuroepigenetic regulation. Bioorg. Med. Chem. Lett. 2016, 26, 1265-1271. [CrossRef]

89. Gurbani, S.S.; Yoon, Y.; Weinberg, B.D.; Salgado, E.; Press, R.H.; Cordova, J.S.; Ramesh, K.K.; Liang, Z.; Vega, J.V.; Voloschin, A.; et al. Assessing Treatment Response of Glioblastoma to an HDAC Inhibitor Using Whole-Brain Spectroscopic MRI. Tomography 2019, 5, 53-60. [CrossRef] [PubMed]

90. Yamawaki, Y.; Yoshioka, N.; Nozaki, K.; Ito, H.; Oda, K.; Harada, K.; Shirawachi, S.; Asano, S.; Aizawa, H.; Yamawaki, S.; et al. Sodium butyrate abolishes lipopolysaccharide-induced depression-like behaviors and hippocampal microglial activation in mice. Brain Res. 2018, 1680, 13-38. [CrossRef]

91. Gundersen, B.B.; Blendy, J.A. Effects of the histone deacetylase inhibitor sodium butyrate in models of depression and anxiety. Neuropharmacology 2009, 57, 67-74. [CrossRef]

92. Schroeder, F.A.; Lin, C.L.; Crusio, W.E.; Akbarian, S. Antidepressant-like effects of the histone deacetylase inhibitor, sodium butyrate, in the mouse. Biol. Psychiatry 2007, 62, 55-64. [CrossRef] 
93. Covington, H.E., 3rd; Vialou, V.F.; LaPlant, Q.; Ohnishi, Y.N.; Nestler, E.J. Hippocampal-dependent antidepressant-like activity of histone deacetylase inhibition. Neurosci. Lett. 2011, 493, 122-126. [CrossRef]

94. Wilkinson, M.B.; Xiao, G.; Kumar, A.; LaPlant, Q.; Renthal, W.; Sikder, D.; Kodadek, T.J.; Nestler, E.J. Imipramine treatment and resiliency exhibit similar chromatin regulation in the mouse nucleus accumbens in depression models. J. Neurosci. 2009, 29, 7820-7832. [CrossRef]

95. Schmauss, C. An HDAC-dependent epigenetic mechanism that enhances the efficacy of the antidepressant drug fluoxetine. Sci. Rep. 2015, 5, 8171. [CrossRef]

96. Ferland, C.L.; Schrader, L.A. Regulation of histone acetylation in the hippocampus of chronically stressed rats: A potential role of sirtuins. Neuroscience 2011, 174, 104-114. [CrossRef] [PubMed]

97. Yamawaki, Y.; Fuchikami, M.; Morinobu, S.; Segawa, M.; Matsumoto, T.; Yamawaki, S. Antidepressant-like effect of sodium butyrate (HDAC inhibitor) and its molecular mechanism of action in the rat hippocampus. World J. Biol. Psychiatry 2012, 13, 458-467. [CrossRef] [PubMed]

98. Lin, H.; Geng, X.; Dang, W.; Wu, B.; Dai, Z.; Li, Y.; Yang, Y.; Zhang, H.; Shi, J. Molecular mechanisms associated with the antidepressant effects of the class I histone deacetylase inhibitor MS-275 in the rat ventrolateral orbital cortex. Brain Res. 2012, 1447, 119-125. [CrossRef] [PubMed]

99. Chen, W.-Y.; Zhang, H.; Gatta, E.; Glover, E.J.; Pandey, S.C.; Lasek, A.W. The histone deacetylase inhibitor suberoylanilide hydroxamic acid (SAHA) alleviates depression-like behavior and normalizes epigenetic changes in the hippocampus during ethanol withdrawal. Alcohol 2019, 78, 79-87. [CrossRef]

100. Park, S.W.; Seo, M.K.; Lee, J.G.; Hien, L.T.; Kim, Y.H. Effects of maternal separation and antidepressant drug on epigenetic regulation of the brain-derived neurotrophic factor exon I promoter in the adult rat hippocampus. Psychiatry Clin. Neurosci. 2018, 72, 255-265. [CrossRef]

101. Qiao, M.; Jiang, Q.-S.; Liu, Y.-J.; Hu, X.-Y.; Wang, L.-J.; Zhou, Q.-X.; Qiu, H.-M. Antidepressant mechanisms of venlafaxine involving increasing histone acetylation and modulating tyrosine hydroxylase and tryptophan hydroxylase expression in hippocampus of depressive rats. Neuroreport 2019, 30, 255-261. [CrossRef]

102. Jiang, H.; Zhang, X.; Lu, J.; Meng, H.; Sun, Y.; Yang, X.; Zhao, B.; Bao, T. Antidepressant-Like Effects of Acupuncture-Insights From DNA Methylation and Histone Modifications of Brain-Derived Neurotrophic Factor. Front. Psychiatry 2018, 9, 102. [CrossRef] [PubMed]

103. Tsankova, N.M.; Kumar, A.; Nestler, E.J. Histone modifications at gene promoter regions in rat hippocampus after acute and chronic electroconvulsive seizures. J. Neurosci. 2004, 24, 5603-5610. [CrossRef] [PubMed]

104. Lopez, J.P.; Mamdani, F.; LaBonte, B.; Beaulieu, M.-M.; Yang, J.P.; Berlim, M.T.; Ernst, C.; Turecki, G. Epigenetic regulation of BDNF expression according to antidepressant response. Mol. Psychiatry 2013, 18, 398-399. [CrossRef]

105. Targum, S.D.; Cameron, B.R.; Ferreira, L.; MacDonald, I.D. An augmentation study of MSI-195 (S-adenosylmethionine) in Major Depressive Disorder. J. Psychiatr. Res. 2018, 107, 86-96. [CrossRef]

106. Gebert, L.F.R.; MacRae, I.J. Regulation of microRNA function in animals. Nat. Rev. Mol. Cell Biol. 2019, 20, 21-37. [CrossRef]

107. Bartel, D.P. MicroRNAs: Target recognition and regulatory functions. Cell 2009, 136, 215-233. [CrossRef]

108. Lytle, J.R.; Yario, T.A.; Steitz, J.A. Target mRNAs are repressed as efficiently by microRNA-binding sites in the $5^{\prime}$ UTR as in the 3' UTR. Proc. Natl. Acad. Sci. USA 2007, 104, 9667-9672. [CrossRef]

109. Lee, I.; Ajay, S.S.; Yook, J.I.; Kim, H.S.; Hong, S.H.; Kim, N.H.; Dhanasekaran, S.M.; Chinnaiyan, A.M.; Athey, B.D. New class of microRNA targets containing simultaneous 5'-UTR and 3'-UTR interaction sites. Genome Res. 2009, 19, 1175-1183. [CrossRef] [PubMed]

110. Forman, J.J.; Coller, H.A. The code within the code: MicroRNAs target coding regions. Cell Cycle 2010, 9, 1533-1541. [CrossRef]

111. Chi, S.W.; Hannon, G.J.; Darnell, R.B. An alternative mode of microRNA target recognition. Nat. Struct. Mol. Biol. 2012, 19, 321-327. [CrossRef] [PubMed]

112. Seok, H.; Ham, J.; Jang, E.S.; Chi, S.W. MicroRNA target recognition: Insights from transcriptome-wide non-canonical interactions. Mol. Cells 2016, 39, 375-381.

113. Liu, H.; Lei, C.; He, Q.; Pan, Z.; Xiao, D.; Tao, Y. Nuclear functions of mammalian MicroRNAs in gene regulation, immunity and cancer. Mol. Cancer 2018, 17, 1-14. [CrossRef]

114. Li, L.-C.; Okino, S.T.; Zhao, H.; Pookot, D.; Place, R.F.; Urakami, S.; Enokida, H.; Dahiya, R. Small dsRNAs induce transcriptional activation in human cells. Proc. Nat. Acad. Sci. USA 2006, 103, 17337-17342. [CrossRef] [PubMed]

115. Huang, V.; Place, R.F.; Portnoy, V.; Wang, J.; Qi, Z.; Jia, Z.; Yu, A.; Shuman, M.; Yu, J.; Li, L.-C. Upregulation of Cyclin B1 by miRNA and its implications in cancer. Nucleic Acids Res. 2012, 40, 1695-1707. [CrossRef] [PubMed]

116. Schwartz, J.C.; Younger, S.T.; Nguyen, N.-B.; Hardy, D.B.; Monia, B.P.; Corey, D.R.; A Janowski, B. Antisense transcripts are targets for activating small RNAs. Nat. Struct. Mol. Biol. 2008, 15, 842-848. [CrossRef] [PubMed]

117. Matsui, M.; Chu, Y.; Zhang, H.; Gagnon, K.T.; Shaikh, S.; Kuchimanchi, S.; Manoharan, M.; Corey, D.R.; Janowski, B.A. Promoter RNA links transcriptional regulation of inflammatory pathway genes. Nucleic Acids Res. 2013, 41, 10086-10109. [CrossRef]

118. Pisignano, G.; Napoli, S.; Magistri, M.; Mapelli, S.N.; Pastori, C.; Di Marco, S.; Civenni, G.; Albino, D.; Enriquez, C.; Allegrini, S.; et al. A promoter-proximal transcript targeted by genetic polymorphism controls E-cadherin silencing in human cancers. Nat. Commun. 2017, 8, 15622. [CrossRef] 
119. Meng, X.; Jiang, Q.; Chang, N.; Wang, X.; Liu, C.; Xiong, J.; Cao, H.; Liang, Z. Small activating RNA binds to the genomic target site in a seed-region-dependent manner. Nucleic Acids Res. 2016, 44, 2274-2282. [CrossRef]

120. Zheng, L.; Chen, Y.; Ye, L.; Jiao, W.; Qiangsong, T.; Mei, H.; Li, D.; Yang, F.; Li, H.; Huang, K.; et al. miRNA-584-3p inhibits gastric cancer progression by repressing Yin Yang 1-facilitated MMP-14 expression. Sci. Rep. 2017, 7, 8967. [CrossRef]

121. Zhang, Y.; Fan, M.; Zhang, X.; Huang, F.; Wu, K.; Zhang, J.; Liu, J.; Huang, Z.; Luo, H.; Tao, L.; et al. Cellular microRNAs up-regulate transcription via interaction with promoter TATA-box motifs. RNA 2014, 20, 1878-1889. [CrossRef] [PubMed]

122. Li, Z.; Lan, X.; Han, R.; Wang, J.; Huang, Y.; Sun, J.; Guo, W.; Chen, H. Erratum: miR-2478 inhibits TGF $\beta 1$ expression by targeting the transcriptional activation region downstream of the TGF $\beta 1$ promoter in dairy goats. Sci. Rep. 2018, 8, 46966. [CrossRef] [PubMed]

123. Zhang, Y.; Zhang, H. RNAa Induced by TATA Box-Targeting MicroRNAs. Adv. Exp. Med. Biol. 2017, 983, 91-111.

124. Paugh, S.W.; Coss, D.R.; Bao, J.; Laudermilk, L.T.; Grace, C.R.; Ferreira, A.M.; Waddell, M.B.; Ridout, G.; Naeve, D.; Leuze, M.; et al. MicroRNAs Form Triplexes with Double Stranded DNA at Sequence-Specific Binding Sites; a Eukaryotic Mechanism via which microRNAs Could Directly Alter Gene Expression. PLoS Comput. Biol. 2016, 12, e1004744. [CrossRef]

125. Toscano-Garibay, J.D.; Aquino-Jarquin, G. Transcriptional regulation mechanism mediated by miRNA-DNA $\bullet$ DNA triplex structure stabilized by Argonaute. Biochim. Biophys. Acta 2014, 1839, 1079-1083. [CrossRef] [PubMed]

126. Włodarski, A.; Strycharz, J.; Wróblewski, A.; Kasznicki, J.; Drzewoski, J.; Śliwińska, A. The Role of microRNAs in Metabolic Syndrome-Related Oxidative Stress. Int. J. Mol. Sci. 2020, 21, 6902. [CrossRef]

127. Roy, B.; Yoshino, Y.; Allen, L.; Prall, K.; Schell, G.; Dwivedi, Y. Exploiting Circulating MicroRNAs as Biomarkers in Psychiatric Disorders. Mol. Diagn. 2020, 24, 279-298. [CrossRef]

128. Iorio, M.V.; Croce, C.M. MicroRNA dysregulation in cancer: Diagnostics, monitoring and therapeutics. A comprehensive review. EMBO Mol. Med. 2012, 4, 143-159. [CrossRef] [PubMed]

129. Singh, T.; Yadav, S. Role of microRNAs in neurodegeneration induced by environmental neurotoxicants and aging. Ageing Res. Rev. 2020, 60, 101068. [CrossRef]

130. Yuan, H.; Mischoulon, D.; Fava, M.; Otto, M.W. Circulating microRNAs as biomarkers for depression: Many candidates, few finalists. J. Affect. Disord. 2018, 233, 68-78. [CrossRef]

131. Dwivedi, Y. Pathogenetic and therapeutic applications of microRNAs in major depressive disorder. Prog. Neuropsychopharmacol. Biol. Psychiatry 2016, 64, 341-348. [CrossRef] [PubMed]

132. Lennox, A.L.; Mao, H.; Silver, D.L. RNA on the brain: Emerging layers of post-transcriptional regulation in cerebral cortex development. Wiley Interdiscip. Rev. Dev. Biol. 2018, 7, e290. [CrossRef] [PubMed]

133. Liu, N.; Wang, Z.Z.; Zhao, M.; Zhang, Y.; Chen, N.H. Role of non-coding RNA in the pathogenesis of depression. Gene 2020, 735, 144276. [CrossRef]

134. Rajasethupathy, P.; Fiumara, F.; Sheridan, R.; Betel, D.; Puthanveettil, S.V.; Russo, J.J.; Sander, C.; Tuschl, T.; Kandel, E. Characterization of small RNAs in Aplysia reveals a role for miR-124 in constraining synaptic plasticity through CREB. Neuron 2009, 63, 803-817. [CrossRef] [PubMed]

135. Schratt, G.M.; Tuebing, F.; Nigh, E.A.; Kane, C.G.; Sabatini, M.E.; Kiebler, M.; Greenberg, M.E. A brain-specific microRNA regulates dendritic spine development. Nature 2006, 439, 283-289. [CrossRef] [PubMed]

136. Chakrapani, S.; Eskander, N.; De Los Santos, L.A.; Omisore, B.A.; Mostafa, J.A. Neuroplasticity and the Biological Role of Brain Derived Neurotrophic Factor in the Pathophysiology and Management of Depression. Cureus 2020, 12, e11396. [CrossRef]

137. Drevets, W.C.; Price, J.L.; Furey, M.L. Brain structural and functional abnormalities in mood disorders: Implications for neurocircuitry models of depression. Brain Struct. Funct. 2008, 213, 93-118. [CrossRef]

138. MacQueen, G.M.; Yucel, K.; Taylor, V.H.; Macdonald, K.; Joffe, R. Posterior hippocampal volumes are associated with remission rates in patients with major depressive disorder. Biol. Psychiatry 2008, 64, 880-883. [CrossRef] [PubMed]

139. Li, N.; Liu, R.-J.; Dwyer, J.M.; Banasr, M.; Lee, B.; Son, H.; Li, X.-Y.; Aghajanian, G.; Duman, R.S. Glutamate N-methyl-D-aspartate receptor antagonists rapidly reverse behavioral and synaptic deficits caused by chronic stress exposure. Biol. Psychiatry 2011, 69, 754-761. [CrossRef]

140. Watanabe, Y.; Gould, E.; McEwen, B.S. Stress induces atrophy of apical dendrites of hippocampal CA3 pyramidal neurons. Brain Res. 1992, 588, 341-345. [CrossRef]

141. Surget, A.; Saxe, M.; Leman, S.; Ibarguen-Vargas, Y.; Chalon, S.; Griebel, G.; Hen, R.; Belzung, C. Drug-dependent requirement of hippocampal neurogenesis in a model of depression and of antidepressant reversal. Biol. Psychiatry 2008, 64, 293-301. [CrossRef]

142. Santarelli, L.; Saxe, M.; Gross, C.; Surget, A.; Battaglia, F.; Dulawa, S.; Weisstaub, N.; Lee, J.; Duman, R.; Arancio, O.; et al. Requirement of hippocampal neurogenesis for the behavioral effects of antidepressants. Science 2003, 301, 805-809. [CrossRef]

143. Boldrini, M.; Santiago, A.N.; Hen, R.; Dwork, A.J.; Rosoklija, G.B.; Tamir, H.; Arango, V.; Mann, J.J. Hippocampal granule neuron number and dentate gyrus volume in antidepressant-treated and untreated major depression. Neuropsychopharmacology 2013, 38, 1068-1077. [CrossRef]

144. Boldrini, M.; Underwood, M.D.; Hen, R.; Rosoklija, G.B.; Dwork, A.J.; Mann, J.J.; Arango, V. Antidepressants increase neural progenitor cells in the human hippocampus. Neuropsychopharmacology 2009, 34, 2376-2389. [CrossRef]

145. Boldrini, M.; Hen, R.; Underwood, M.D.; Rosoklija, G.B.; Dwork, A.J.; Mann, J.J.; Arango, V. Hippocampal angiogenesis and progenitor cell proliferation are increased with antidepressant use in major depression. Biol. Psychiatry 2012, 72, 562-571. [CrossRef] 
146. Duman, R.S.; Aghajanian, G.K. Synaptic dysfunction in depression: Potential therapeutic targets. Science 2012, 338, 68-72. [CrossRef]

147. Davis, T.H.; Cuellar, T.L.; Koch, S.M.; Barker, A.J.; Harfe, B.D.; McManus, M.T.; Ullian, E.M. Conditional loss of Dicer disrupts cellular and tissue morphogenesis in the cortex and hippocampus. J. Neurosci. 2008, 28, 4322-4330. [CrossRef]

148. Schaefer, A.; O'Carroll, D.; Tan, C.L.; Hillman, D.; Sugimori, M.; Llinas, R.; Greengard, P. Cerebellar neurodegeneration in the absence of microRNAs. J. Exp. Med. 2007, 204, 1553-1558. [CrossRef]

149. Stark, K.L.; Xu, B.; Bagchi, A.; Lai, W.-S.; Liu, H.; Hsu, R.; Wan, X.; Pavlidis, P.; A Mills, A.; Karayiorgou, M.; et al. Altered brain microRNA biogenesis contributes to phenotypic deficits in a 22q11-deletion mouse model. Nat. Genet. 2008, 40, 751-760. [CrossRef]

150. Carniel, B.P.; da Rocha, N.S. Brain-derived neurotrophic factor (BDNF) and inflammatory markers: Perspectives for the management of depression. Prog. Neuropsychopharmacol. Biol. Psychiatry 2020, 110151. [CrossRef] [PubMed]

151. Wan, Y.; Liu, Y.; Wang, X.; Wu, J.; Liu, K.; Zhou, J.; Liu, L.; Zhang, C. Identification of differential microRNAs in cerebrospinal fluid and serum of patients with major depressive disorder. PLoS ONE 2015, 10, e0121975. [CrossRef]

152. Fan, H.-M.; Sun, X.-Y.; Guo, W.; Zhong, A.-F.; Niu, W.; Zhao, L.; Dai, Y.-H.; Guo, Z.-M.; Zhang, L.-Y.; Lu, J. Differential expression of microRNA in peripheral blood mononuclear cells as specific biomarker for major depressive disorder patients. J. Psychiatr. Res. 2014, 59, 45-52. [CrossRef] [PubMed]

153. Smalheiser, N.R. The RNA-centred view of the synapse: Non-coding RNAs and synaptic plasticity. Philos. Trans. R. Soc. Lond B Biol. Sci. 2014, 369. [CrossRef] [PubMed]

154. Baudry, A.; Mouillet-Richard, S.; Schneider, B.; Launay, J.-M.; Kellermann, O. miR-16 targets the serotonin transporter: A new facet for adaptive responses to antidepressants. Science 2010, 329, 1537-1541. [CrossRef] [PubMed]

155. Launay, J.M.; Mouillet-Richard, S.; Baudry, A.; Pietri, M.; Kellermann, O. Raphe-mediated signals control the hippocampal response to SRI antidepressants via miR-16. Transl. Psychiatry 2011, 1, e56. [CrossRef] [PubMed]

156. Song, M.-F.; Dong, J.-Z.; Wang, Y.-W.; He, J.; Ju, X.; Zhang, L.; Zhang, Y.-H.; Shi, J.-F.; Lv, Y.-Y. CSF miR-16 is decreased in major depression patients and its neutralization in rats induces depression-like behaviors via a serotonin transmitter system. J. Affect. Disord. 2015, 178, 25-31. [CrossRef]

157. Zurawek, D.; Kusmider, M.; Faron-Gorecka, A.; Gruca, P.; Pabian, P.; Kolasa, M.; Solich, J.; Szafran-Pilch, K.; Papp, M.; DziedzickaWasylewska, M. Time-dependent miR-16 serum fluctuations together with reciprocal changes in the expression level of miR-16 in mesocortical circuit contribute to stress resilient phenotype in chronic mild stress-An animal model of depression. Eur. Neuropsychopharmacol. 2016, 26, 23-36. [CrossRef]

158. Gallego, J.A.; Gordon, M.L.; Claycomb, K.; Bhatt, M.; Lencz, T.; Malhotra, A.K. In vivo microRNA detection and quantitation in cerebrospinal fluid. J. Mol. Neurosci. 2012, 47, 243-248. [CrossRef] [PubMed]

159. Xu, Y.Y.; Xia, Q.H.; Xia, Q.R.; Zhang, X.L.; Liang, J. Microrna-based biomarkers in the diagnosis and monitoring of therapeutic response in patients with depression. Neuropsychiatr. Dis. Treat. 2019, 15, 3583-3597. [CrossRef]

160. Van den Berg, M.M.J.; Krauskopf, J.; Ramaekers, J.G.; Kleinjans, J.C.S.; Prickaerts, J.; Briedé, J.J. Circulating microRNAs as potential biomarkers for psychiatric and neurodegenerative disorders. Prog. Neurobiol. 2020, 185, 101732. [CrossRef]

161. Stoicea, N.; Du, A.; Lakis, D.C.; Tipton, C.; Arias-Morales, C.E.; Bergese, S.D. The MiRNA Journey from Theory to Practice as a CNS Biomarker. Front. Genet. 2016, 7, 11. [CrossRef]

162. Wei, D.; Wan, Q.; Li, L.; Jin, H.; Liu, Y.; Wang, Y.; Zhang, G. MicroRNAs as Potential Biomarkers for Diagnosing Cancers of Central Nervous System: A Meta-analysis. Mol. Neurobiol. 2015, 51, 1452-1461. [CrossRef] [PubMed]

163. Iwata, M.; Ota, K.T.; Duman, R.S. The inflammasome: Pathways linking psychological stress, depression, and systemic illnesses. Brain Behav. Immun. 2013, 31, 105-114. [CrossRef] [PubMed]

164. Moschos, S.A.; Williams, A.E.; Perry, M.M.; Birrell, M.A.; Belvisi, M.G.; Lindsay, M.A. Expression profiling in vivo demonstrates rapid changes in lung microRNA levels following lipopolysaccharide-induced inflammation but not in the anti-inflammatory action of glucocorticoids. BMC Genom. 2007, 8, 240. [CrossRef]

165. Belzeaux, R.; Lin, R.; Turecki, G. Potential Use of MicroRNA for Monitoring Therapeutic Response to Antidepressants. CNS Drugs 2017, 31, 253-262. [CrossRef]

166. O'Connor, R.M.; Grenham, S.; Dinan, T.G.; Cryan, J.F. microRNAs as novel antidepressant targets: Converging effects of ketamine and electroconvulsive shock therapy in the rat hippocampus. Int. J. Neuropsychopharmacol. 2013, 16, 1885-1892. [CrossRef]

167. Vasu, M.M.; Anitha, A.; Takahashi, T.; Thanseem, I.; Iwata, K.; Asakawa, T.; Suzuki, K. Fluoxetine Increases the Expression of miR-572 and miR-663a in Human Neuroblastoma Cell Lines. PLoS ONE 2016, 11, e0164425.

168. Issler, O.; Haramati, S.; Paul, E.D.; Maeno, H.; Navon, I.; Zwang, R.; Gil, S.; Mayberg, H.S.; Dunlop, B.W.; Menke, A.; et al. MicroRNA 135 is essential for chronic stress resiliency, antidepressant efficacy, and intact serotonergic activity. Neuron 2014, 83, 344-360. [CrossRef]

169. Schmidt, U.; Herrmann, L.; Hagl, K.; Novak, B.; Huber, C.; Holsboer, F.; Wotjak, C.T.; Buell, D.R. Therapeutic Action of Fluoxetine is Associated with a Reduction in Prefrontal Cortical miR-1971 Expression Levels in a Mouse Model of Posttraumatic Stress Disorder. Front. Psychiatry 2013, 4, 66. [CrossRef] [PubMed]

170. Angelucci, F.; Croce, N.; Spalletta, G.; DiNallo, V.; Gravina, P.; Bossù, P.; Federici, G.; Caltagirone, C.; Bernardini, S. Paroxetine rapidly modulates the expression of brain-derived neurotrophic factor mRNA and protein in a human glioblastoma-astrocytoma cell line. Pharmacology 2011, 87, 5-10. [CrossRef] 
171. Oved, K.; Morag, A.; Pasmanik-Chor, M.; Oron-Karni, V.; Shomron, N.; Rehavi, M.; Stingl, J.C.; Gurwitz, D. Genome-wide miRNA expression profiling of human lymphoblastoid cell lines identifies tentative SSRI antidepressant response biomarkers. Pharmacogenomics 2012, 13, 1129-1139. [CrossRef]

172. Kuang, W.-H.; Dong, Z.-Q.; Tian, L.-T.; Li, J. MicroRNA-451a, microRNA-34a-5p, and microRNA-221-3p as predictors of response to antidepressant treatment. Braz. J. Med. Biol. Res. 2018, 51, e7212. [CrossRef] [PubMed]

173. Lopez, J.P.; Lim, R.; Cruceanu, C.; Crapper, L.; Fasano, C.; LaBonte, B.; Maussion, G.; Yang, J.P.; Yerko, V.; Vigneault, E.; et al. miR-1202 is a primate-specific and brain-enriched microRNA involved in major depression and antidepressant treatment. Nat. Med. 2014, 20, 764-768. [CrossRef]

174. Fang, Y.; Qiu, Q.; Zhang, S.; Sun, L.; Li, G.; Xiao, S.; Li, X. Changes in miRNA-132 and miR-124 levels in non-treated and citalopram-treated patients with depression. J. Affect. Disord. 2018, 227, 745-751. [CrossRef]

175. Zhang, Y.; Wang, Y.; Wang, L.; Bai, M.; Zhang, X.; Zhu, X. Dopamine Receptor D2 and Associated microRNAs Are Involved in Stress Susceptibility and Resistance to Escitalopram Treatment. Int. J. Neuropsychopharmacol. 2015, 18. [CrossRef]

176. Bocchio-Chiavetto, L.; Maffioletti, E.; Bettinsoli, P.; Giovannini, C.; Bignotti, S.; Tardito, D.; Corrada, D.; Milanesi, L.; Gennarelli, M. Blood microRNA changes in depressed patients during antidepressant treatment. Eur. Neuropsychopharmacol. 2013, 23, 602-611. [CrossRef] [PubMed]

177. Lopez, J.P.; Fiori, L.M.; Cruceanu, C.; Lin, R.; LaBonte, B.; Cates, H.M.; Heller, E.A.; Vialou, V.; Ku, S.M.; Gerald, C.; et al. MicroRNAs $146 \mathrm{a} / \mathrm{b}-5$ and $425-3 \mathrm{p}$ and 24-3p are markers of antidepressant response and regulate MAPK/Wnt-system genes. Nat. Commun. 2017, 8, 15497. [CrossRef]

178. Pan, B.; Liu, Y. Effects of duloxetine on microRNA expression profile in frontal lobe and hippocampus in a mouse model of depression. Int. J. Clin. Exp. Pathol. 2015, 8, 15454-15461.

179. Lopez, J.P.; Pereira, F.R.S.; Richard-Devantoy, S.; Berlim, M.; Chachamovich, E.; Fiori, L.M.; Niola, P.; Turecki, G.; Jollant, F. Co-Variation of Peripheral Levels of miR-1202 and Brain Activity and Connectivity During Antidepressant Treatment. Neuropsychopharmacology 2017, 42, 2043-2051. [CrossRef]

180. Yang, X.; Yang, Q.; Wang, X.; Luo, C.; Wan, Y.; Li, J.; Liu, K.; Zhou, M.; Zhang, C. MicroRNA expression profile and functional analysis reveal that miR-206 is a critical novel gene for the expression of BDNF induced by ketamine. Neuromol. Med. 2014, 16, 594-605. [CrossRef] [PubMed]

181. Ryan, K.M.; O’Donovan, S.M.; McLoughlin, D.M. Electroconvulsive stimulation alters levels of BDNF-associated microRNAs. Neurosci. Lett. 2013, 549, 125-129. [CrossRef]

182. Kolshus, E.; Ryan, K.M.; Blackshields, G.; Smyth, P.; Sheils, O.; McLoughlin, D.M. Peripheral blood microRNA and VEGFA mRNA changes following electroconvulsive therapy: Implications for psychotic depression. Acta Psychiatr. Scand. 2017, 136, 594-606. [CrossRef] [PubMed]

183. Gururajan, A.; E Naughton, M.; A Scott, K.; O'Connor, R.M.; Moloney, G.; Clarke, G.; Dowling, J.; Walsh, A.; Ismail, F.; Shorten, G.; et al. MicroRNAs as biomarkers for major depression: A role for let-7b and let-7c. Transl. Psychiatry 2016, 6, e862 [CrossRef] [PubMed]

184. He, S.; Liu, X.; Jiang, K.; Peng, D.; Hong, W.; Huafang, L.; Qian, Y.; Yu, S.; Li, H. Alterations of microRNA-124 expression in peripheral blood mononuclear cells in pre- and post-treatment patients with major depressive disorder. J. Psychiatr. Res. 2016, 78, 65-71. [CrossRef] [PubMed]

185. Belzeaux, R.; Bergon, A.; Jeanjean, V.; Loriod, B.; Formisano-Tréziny, C.; Verrier, L.; Loundou, A.; Baumstarck-Barrau, K.; Boyer, L.; Gall, V.; et al. Responder and nonresponder patients exhibit different peripheral transcriptional signatures during major depressive episode. Transl. Psychiatry 2012, 2, e185. [CrossRef]

186. Schmitz, S.U.; Grote, P.; Herrmann, B.G. Mechanisms of long noncoding RNA function in development and disease. Cell. Mol. Life Sci. 2016, 73, 2491-2509. [CrossRef]

187. Chen, X.; Sun, Y.; Cai, R.; Wang, G.; Shu, X.; Pang, W. Long noncoding RNA: Multiple players in gene expression. BMB Rep. 2018, 51, 280-289. [CrossRef]

188. Tsagakis, I.; Douka, K.; Birds, I. Long non-coding RNAs in development and disease: Conservation to mechanisms. J. Pathol. 2020, 250, 480-495. [CrossRef]

189. Huang, X.; Luo, Y.-L.; Mao, Y.-S.; Ji, J.-L. The link between long noncoding RNAs and depression. Prog. Neuro-Psychopharmacol. Biol. Psychiatry 2017, 73, 73-78. [CrossRef]

190. Cui, X.; Sun, X.; Niu, W.; Kong, L.; He, M.; Zhong, A.; Chen, S.; Jiang, K.; Zhang, L.; Cheng, Z. Long non-coding RNA: Potential diagnostic and therapeutic biomarker for major depressive disorder. Med. Sci. Monit. 2016, 22, 5240-5248. [CrossRef] [PubMed]

191. Zhang, T.-N.; Goodwin, J.E.; Liu, B.; Li, D.; Wen, R.; Yang, N.; Xia, J.; Zhou, H.; Zhang, T.; Song, W.-L.; et al. Characterization of Long Noncoding RNA and mRNA Profiles in Sepsis-Induced Myocardial Depression. Mol. Nucleic Acids 2019, 17, 852-866. [CrossRef] [PubMed]

192. Chen, L.L. Linking Long Noncoding RNA Localization and Function. Trends Biochem. Sci. 2016, 41, 761-772. [CrossRef]

193. Awan, H.M.; Shah, A.; Rashid, F.; Shan, G. Primate-specific Long Non-coding RNAs and MicroRNAs. Genom. Proteom. Bioinf. 2017, 15, 187-195. [CrossRef]

194. Ma, L.; Bajic, V.B.; Zhang, Z. On the classification of long non-coding RNAs. RNA Biol. 2013, 10, 924-933. [CrossRef]

195. Wu, P.; Zuo, X.; Deng, H.; Liu, X.; Liu, L.; Ji, A. Roles of long noncoding RNAs in brain development, functional diversification and neurodegenerative diseases. Brain Res. Bull. 2013, 97, 69-80. [CrossRef] 
196. Guennewig, B.; Cooper, A.A. The central role of noncoding RNA in the brain. Int. Rev. Neurobiol. 2014, 116, 153-194.

197. Torres-Berrío, A.; Issler, O.; Parise, E.M.; Nestler, E.J. Unraveling the epigenetic landscape of depression: Focus on early life stress. Dialogues Clin. Neurosci. 2019, 21, 341-357. [PubMed]

198. Chen, S.; Zhu, X.; Niu, W.; Yao, G.; Kong, L.; He, M.; Chen, C.; Lu, Z.; Cui, X.; Zhang, L. Regulatory Role of lncRNA NONHSAT089447 in the Dopamine Signaling Pathway in Schizophrenic Patients. Med. Sci. Monit. 2019, 25, 4322-4332. [CrossRef] [PubMed]

199. Hosseini, E.; Bagheri-Hosseinabadi, Z.; De Toma, I.; Jafarisani, M.; Sadeghi, I. The importance of long non-coding RNAs in neuropsychiatric disorders. Mol. Asp. Med. 2019, 70, 127-140. [CrossRef]

200. Li, C.; Cao, F.; Li, S.; Huang, S.; Li, W.; Abumaria, N. Profiling and co-expression network analysis of learned helplessness regulated mRNAs and lncRNAs in the mouse hippocampus. Front. Mol. Neurosci. 2018, 10, 1-13. [CrossRef]

201. Liu, S.; Zhou, B.; Wang, L.; Hu, H.; Yao, C.; Cai, Z.; Cui, X. Therapeutic antidepressant potential of NONHSAG045500 in regulating serotonin transporter in major depressive disorder. Med. Sci. Monit. 2018, 24, 4465-4473. [CrossRef] [PubMed]

202. Cui, X.; Niu, W.; Kong, L.; He, M.; Jiang, K.; Chen, S.; Zhong, A.; Li, W.; Lu, J.; Zhang, L. Long noncoding RNA expression in peripheral blood mononuclear cells and suicide risk in Chinese patients with major depressive disorder. Brain Behav. 2017, 7, 1-7. [CrossRef] [PubMed]

203. Zhang, J.; Xue, M.; Mei, Y.; Li, Z.; Ceng, Z.; Li, Y.; Zhang, Y.; Li, N.; Teng, H.; Sun, Z.S.; et al. Co-expression Network of mRNAs and IncRNAs Regulated by Stress-Linked Behavioral Assays. Psychopharmacology 2020, 237, 571-582. [CrossRef]

204. Watson, C.N.; Belli, A.; Pietro, V.; Di Budini, M.F. Small Non-coding RNAs: New Class of Biomarkers and Potential Therapeutic Targets in Neurodegenerative Disease. Front. Genet. 2019, 10, 1-14. [CrossRef]

205. Liu, Z.; Li, X.; Sun, N.; Xu, Y.; Meng, Y.; Yang, C.; Wang, Y.; Zhang, K. Microarray Profiling and Co-Expression Network Analysis of Circulating lncRNAs and mRNAs Associated with Major Depressive Disorder. PLoS ONE 2014, 9. [CrossRef] [PubMed]

206. Cui, X.; Niu, W.; Kong, L.; He, M.; Jiang, K.; Chen, S.; Zhong, A.; Zhang, Q.; Li, W.; Lu, J.; et al. Long noncoding RNA as an indicator differentiating schizophrenia from major depressive disorder and generalized anxiety disorder in nonpsychiatric hospital. Biomark. Med. 2017, 11, 221-228. [CrossRef]

207. Cui, X.; Niu, W.; Kong, L.; He, M.; Jiang, K.; Chen, S.; Zhong, A.; Li, W.; Lu, J.; Zhang, L. Can lncRNAs be indicators for the diagnosis of early onset or acute schizophrenia and distinguish major depressive disorder and generalized anxiety disorder?-A cross validation analysis. Am. J. Med. Genet. Part. B Neuropsychiatr. Genet. 2017, 174, 335-341. [CrossRef]

208. Carter, G.; Miladinovic, B.; Patel, A.A.; Deland, L.; Mastorides, S.; Patel, N.A. Circulating long noncoding RNA GAS5 levels are correlated to prevalence of type 2 diabetes mellitus. BBA Clin. 2015, 4, 102-107. [CrossRef]

209. Pandey, G.K.; Mitra, S.; Subhash, S.; Hertwig, F.; Kanduri, M.; Mishra, K.; Fransson, S.; Ganeshram, A.; Mondal, T.; Bandaru, S.; et al. The Risk-Associated Long Noncoding RNA NBAT-1 Controls Neuroblastoma Progression by Regulating Cell Proliferation and Neuronal Differentiation. Cancer Cell 2014, 26, 722-737. [CrossRef]

210. Thin, K.Z. Clinica Chimica Acta. Clin. Chim. Acta 2019, 494, 38-47. [CrossRef] 